\title{
Techno-Economic Analysis of Integration of Low-Temperature Geothermal Resources for Coal- Fired Power Plants
}

\section{May 2016}
MD Bearden
DJ Heldebrant
CL Davidson
CJ Freeman

JA Horner 



\title{
DISCLAIMER
}

This report was prepared as an account of work sponsored by an agency of the United States Government. Neither the United States Government nor any agency thereof, nor Battelle Memorial Institute, nor any of their employees, makes any warranty, express or implied, or assumes any legal liability or responsibility for the accuracy, completeness, or usefulness of any information, apparatus, product, or process disclosed, or represents that its use would not infringe privately owned rights. Reference herein to any specific commercial product, process, or service by trade name, trademark, manufacturer, or otherwise does not necessarily constitute or imply its endorsement, recommendation, or favoring by the United States Government or any agency thereof, or Battelle Memorial Institute. The views and opinions of authors expressed herein do not necessarily state or reflect those of the United States Government or any agency thereof.

\author{
PACIFIC NORTHWEST NATIONAL LABORATORY \\ operated by \\ BATTELLE \\ for the \\ UNITED STATES DEPARTMENT OF ENERGY \\ under Contract DE-AC05-76RL01830
}

Printed in the United States of America
Available to DOE and DOE contractors from the Office of Scientific and Technical Information,
P.O. Box 62, Oak Ridge, TN 37831-0062;
ph: (865) 576-8401
fax: $(865)$ 576-5728
email: reports@adonis.osti.gov

\begin{abstract}
Available to the public from the National Technical Information Service, U.S. Department of Commerce, 5285 Port Royal Rd., Springfield, VA 22161 ph: (800) 553-6847 fax: $(703) 605-6900$ email: orders@ntis.fedworld.gov online ordering: http://www.ntis.gov/ordering.htm
\end{abstract}

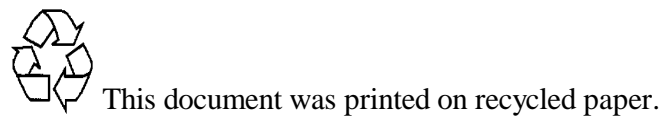



Project Update

Project Deliverable (Task 3)

Techno-Economic Analysis of Integration of Low-Temperature Geothermal Resources for Coal-Fired Power Plants.

Prepared by:

Mark Bearden, Casie Davidson, Jake Horner, David Heldebrant, and Charles Freeman

October 30, 2015

AOP PROJECT 27342

SUBMITTED BY

Pacific Northwest National Laboratory

902 Battelle Boulevard

P.O Box 999

Richland, WA 99354-1793

PRINCIPAL INVESTIGATORS:

David J. Heldebrant, PhD

Phone: 509-772-6359

Fax: 509-375-2186

david.heldebrant@pnnl.gov

Casie Davidson

Phone: 509-372-6259

Fax: 509-375-6393

Casie.davidson@pnnl.gov

\section{SUBMITTED TO:}

U.S. Department of Energy

Geothermal Technologies Office 



\section{Acronyms and Abbreviations}

$\begin{array}{ll}\text { CCS } & \mathrm{CO}_{2} \text { capture and geologic storage } \\ \text { DOE } & \text { U.S. Department of Energy } \\ \text { EIA } & \text { Energy Information Administration } \\ \text { FGD } & \text { Flue gas desulfurization } \\ \text { LCOE } & \text { levelized cost of electricity } \\ \text { MEA } & \text { monoethanolamine (considered the standard amine-based } \mathrm{CO}_{2} \text { scrubbing technology) } \\ \text { NETL } & \text { National Energy Technology Laboratory } \\ \text { ORC } & \text { Organic Rankine Cycle } \\ \text { PC } & \text { pulverized coal } \\ \text { TEA } & \text { techno-economic (study) } \\ \text { USGS } & \text { U.S. Geological Survey }\end{array}$





\section{Contents}

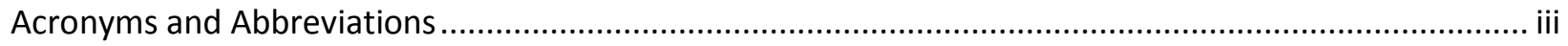

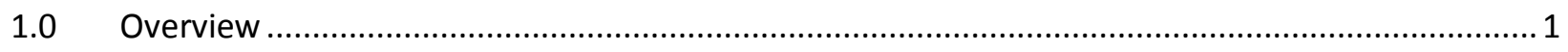

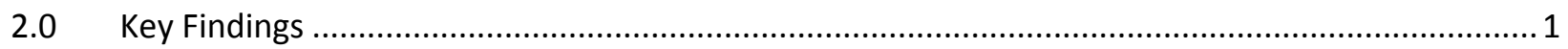

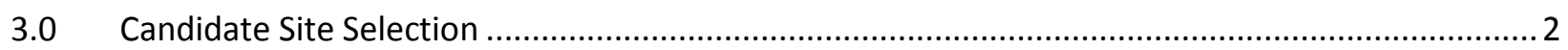

4.0 Summary of Resource Availability and Well Cost Projections (North Valmy) ............................... 3

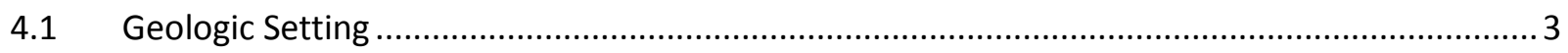

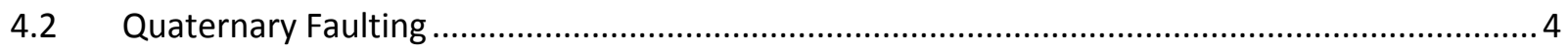

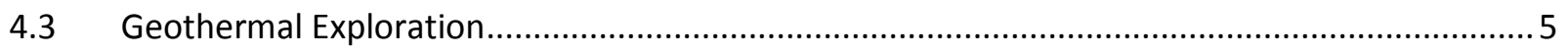

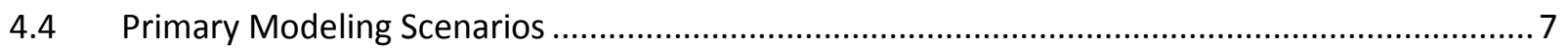

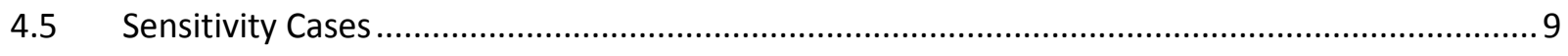

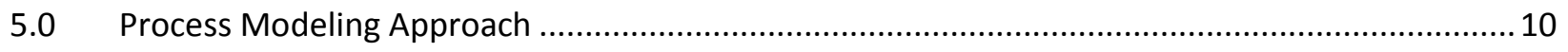

5.1 Simulations of Geothermal Boiler Feed Water Heating at North Valmy ..................................12

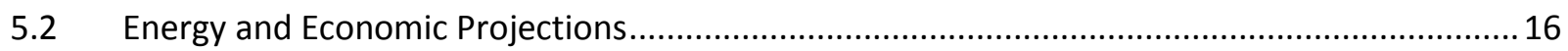

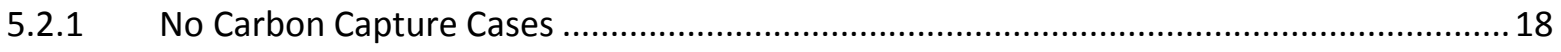

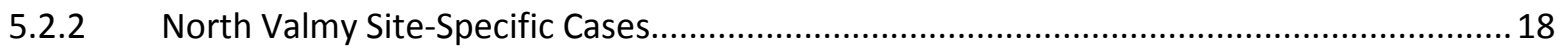

5.2.3 With Carbon Capture Cases ................................................................................. 19

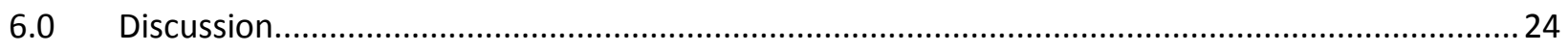

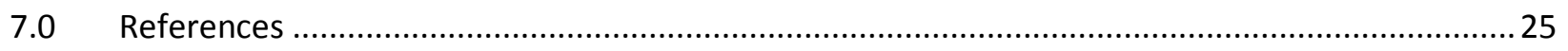

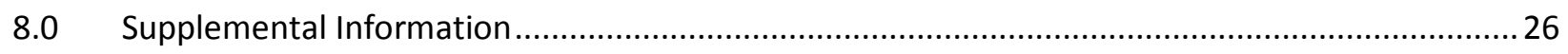





\section{Figures}

1 Preliminary options. (Data on coal power stations c. 2011, from Platts; geothermal resource maps, Google Earth/World Energy Explorer) ............................................................... 2

2 Map showing locations of the North Valmy power plant and other key areas discussed in this

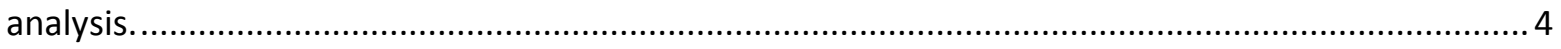

3 Location of potential Quaternary fault scarps along the northwest flank of Treaty Hill.................... 5

4 Temperature gradient contours and potential drilling locations at the Hot Pot project ................... 7

5 Location of Oski Energy, LLC geothermal leases, the Hot Pot seismic program survey lines, and interpreted structures.............................................................................................................. 7

$7 \quad$ North Valmy power plant layout as shown from Google Maps. ..................................................... 12

8 Cumulative air temperature frequency in Winnemucca, Nevada .................................................. 14

9 Comparison of net electric power and levelized cost of electricity estimates for each model case.. 22

\section{Tables}

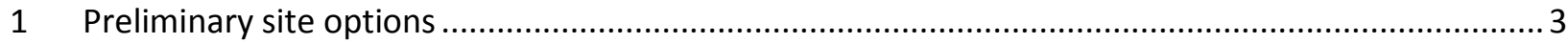

2 Site-specific cost parameters and resulting cost estimates for production and injection well requirements at North Valmy power plant. .................................................................................. 8

3 Comparison of water use for all wet and wet/dry cooling ................... Error! Bookmark not defined.

4 Hybrid direct-use geothermal $125^{\circ} \mathrm{C}$ water providing carbon capture solvent re-boiler duty ..........15

$5 \quad$ Net electric power and fuel cost estimates for each model case .............................................. 17

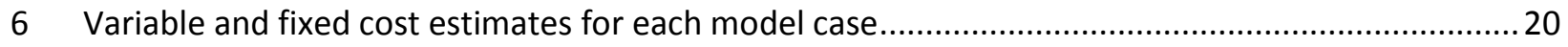

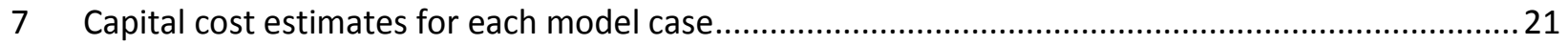

$8 \quad$ Levelized cost of electricity estimates for each model case ........................................................22 


\subsection{Overview}

Presented here are the results of a techno-economic (TEA) study of the potential for coupling low-grade geothermal resources to boost the electrical output from coal-fired power plants. This study includes identification of candidate $500 \mathrm{MW}$ subcritical coal-fired power plants in the continental United States, followed by down-selection and characterization of the North Valmy generating station, a Nevada coal-fired plant. Based on site and plant characteristics, ASPEN Plus models were designed to evaluate options to integrate geothermal resources directly into existing processes at North Valmy. Energy outputs and capital costing are presented for numerous hybrid strategies, including integration with Organic Rankine Cycles (ORCs), which currently represent the primary technology for baseload geothermal power generation.

\subsection{Key Findings}

The results of this study suggest that, where geothermal resources can be accessed by plant operators, direct use of low-grade geothermal resources can increase net power production of coal-fired plants, with the potential to partially or fully offset the efficiency penalties associated with $\mathrm{CO}_{2}$ capture. Where $\mathrm{CO}_{2}$ capture is not yet sufficiently incentivized, this reflects an intriguing hybrid approach that could enable more energy efficient power generation from conventional fossil-fired generation units. By leveraging the existing capital present across the U.S. power fleet, this hybrid approach also offers an opportunity to develop low-temperature resources at costs of electricity that outperform generation from these marginal resources using ORC. While this project evaluated a specific coal-fired plant paired with a marginal geothermal resource located very near the plant site, the applicability of this hybrid approach may well be much broader, particularly for the existing gas-fired power fleet, as well as for future fossil-fired generation facilities.

Key findings of this analysis include:

- Direct use of $150^{\circ} \mathrm{C}$ geothermal water $(185,000 \mathrm{bbl} /$ day) is estimated to generate an additional 19 MWe on the reference subcritical coal-fired power plant via boiler feed water preheating alone. ${ }^{1}$ First passing the same geothermal water through an ORC prior to using it for preheating is estimated to produce less overall net power than using it solely for boiler feed water preheating.

- Several scenarios were investigated where geothermal water was used to offset the duties associated with a $\mathrm{CO}_{2}$ capture process installed on a subcritical coal-fired power plant.

o The modeling cases with MEA carbon capture predicted massive amounts of geothermal water required to fully offset the MEA regeneration energy need. These water flow rates are not considered feasible for a geothermal resource on a single site.

o A modest geothermal resource $(2,700,000 \mathrm{lb} / \mathrm{hr})$ is estimated to offset approximately $7 \%$ of a MEA solvent re-boiler duty, resulting in marginal impacts to overall Levelized Cost of Electricity (LCOE) associated with $\mathrm{CO}_{2}$ capture and geologic storage (CCS). 
o For an advanced carbon capture solvent system such as $\mathrm{CO}_{2} \mathrm{BOLs}$, with a regeneration temperature more than $30^{\circ} \mathrm{Clower}$ than amines, $90 \%$ of the re-boiler duty could be offset by $150^{\circ} \mathrm{C}$ geothermal water, equating to $123 \mathrm{MWe}$ of extra power generation. The approximately $685,000 \mathrm{bbl} /$ day of geothermal water required in this scenario is significant, but within reason for a single power generation site. Compared to the MEA solvent case, this geothermal-enabled $\mathrm{CO}_{2}$ capture scenario results in an overall LCOE reduction of of 0.75 cents per kWe-hr, suggesting an opportunity to address $\mathrm{CO}_{2}$ capture requirements while also expanding the applicability for geothermal energy at costs that could prove to be appealing investments, particularly once financial incentives exist to spur CCS deployment in the U.S. power sector.

- Sensitivity analysis suggests that, as expected, economics are sensitive to geothermal flow rate and resource temperature, although break-even rates and temperatures are expected to be highly project specific.

\subsection{Candidate Site Selection}

The Task 2 deliverable identified 10 candidate power subcritical 500 to $750 \mathrm{MW}$ plants with geothermal resources between 125 and $150^{\circ} \mathrm{C}$ at a $3.5 \mathrm{~km}$ depth Figure 1 and Table 1 . Of those ten, four sites were selected for additional screening.

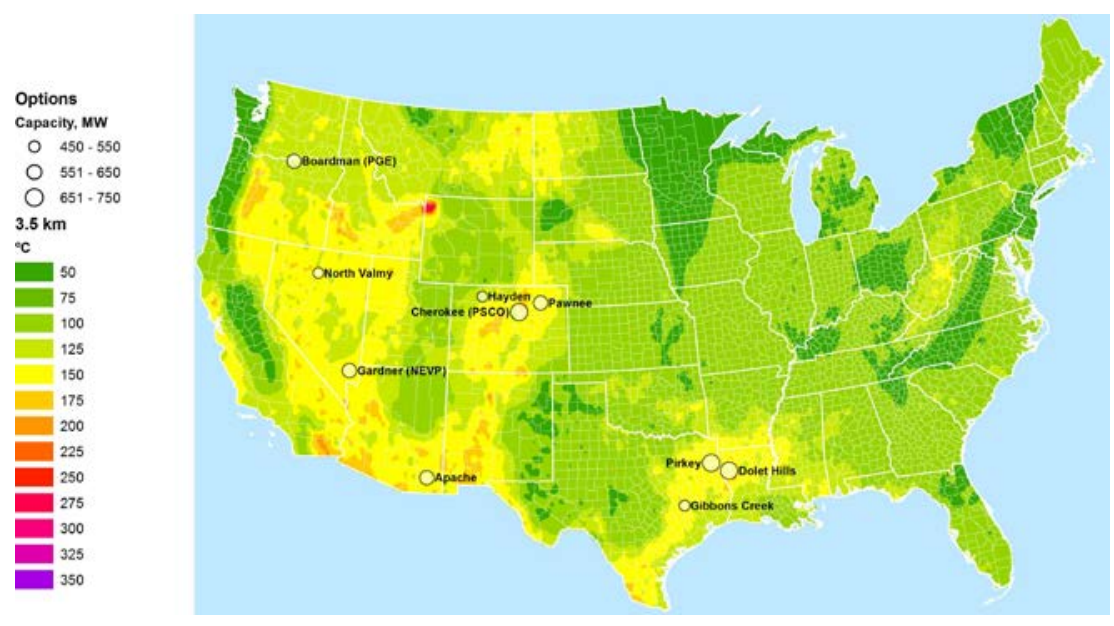

Figure 1. Preliminary options. (Data on coal power stations c. 2011, from Platts; geothermal resource maps, Google Earth / World Energy Explorer.)

The Apache, Boardman, Hayden, and North Valmy plants were selected for the engineering assessments of potential direct-use geothermal integration. Each candidate plant represents a different region of the continental United States, reflecting four unique geologic settings and covering a range of conceptual reservoir models with varying degrees of potential resource availability. Additionally, these plants were selected based on project feasibility, particularly regarding permitting of well drilling and stimulation. It should be noted that many of the 602 coal-fired plants in the continental United States may benefit to some degree the projected benefit from the geothermal integration strategies described in Section 4 but the resource availability may require deeper resource extraction and/or reservoir stimulation, and thus could 
incur significantly higher extraction costs. The North Valmy plant was chosen for the detailed economics of this study (Section 5) because of the quality of data available on a potential hydrothermal resource at the site. North Valmy reflected the best opportunity to model this hybrid concept using actual plant data paired with a known resource.

Table 1. Preliminary site options

\begin{tabular}{|lcccc|}
\hline Plant & $\begin{array}{c}\text { Capacity } \\
\text { (MW) }\end{array}$ & $\begin{array}{c}\text { Location } \\
\text { (City, ST) }\end{array}$ & $\begin{array}{c}\text { Vintage } \\
\text { (First, Last) }\end{array}$ & $\begin{array}{c}\text { Approx Temp } \\
\text { @ 3.5 km ( }\end{array}$ C) \\
\hline Apache & 627 & Cochise, AZ & 1963,2002 & 150 \\
\hline Boardman & 601 & Boardman, OR & 1980,1980 & $125-150$ \\
\hline Cherokee & 730 & Denver, CO & 1957,1988 & $125-175$ \\
\hline Dolet Hills & 720 & Mansfield, LA & 1986,1986 & 150 \\
\hline Gardner & 637 & Moapa, NV & 1965,1983 & 150 \\
\hline Gibbons Creek & 470 & Grimes, TX & 1983,1983 & $150-175$ \\
\hline Hayden & 465 & Hayden, CO & 1965,1976 & 125 \\
\hline North Valmy & 521 & Valmy, NV & 1981,1985 & 150 \\
\hline Pawnee & 552 & Brush, CO & 1981,1981 & 150 \\
\hline Pirkey & 721 & Hallsville, TX & 1985,1985 & 150 \\
\hline
\end{tabular}

\subsection{Summary of Resource Availability and Well Cost Projections (North Valmy)}

\subsection{Geologic Setting}

The North Valmy power plant is located in the Humboldt River Valley and is surrounded by steep mountain ranges that expose a complex geologic history of early accretionary orogenic events followed by rifting and extension of the Great Basin. In the absence of deep borehole investigations within the Humboldt Valley region, the subsurface geology near the North Valmy site can only be surmised from the geology of nearby outcrops, mine pits, and surrounding mountain ranges. Rocks exposed in the surrounding ranges and in the local Lone Tree mine (Figure 2) are dominated by Paleozoic sediments, which include the Valmy Formation, Antler sequence, and Havallah sequence. These rocks formed offshore, and were emplaced by thrust faults onto the western margin of North America in separate events during the Paleozoic and early Triassic. The Ordovician Valmy Formation is generally considered to be an allochthon of the Roberts Mountain Thrust and consists of complexly faulted deep marine siliceous and volcanic rocks. The Antler sequence represents marine transgression and unconformably overlaps the deformed Valmy Formation. ${ }^{2}$ Locally, at the Lone Tree mine, the Antler overlap sequence is limited to siltstone and sandstones of the Permian age Edna Mountain Formation. ${ }^{3}$ The Havallah sequence is a structurally complex assemblage of thrust packages of upper Paleozoic rocks that were emplaced over rocks of the Antler overlap sequence along the Golconda Thrust. At the Lone Tree mine, the Havallah Formation is divided into two units which include: 1) a chert, argillite, and greenstone unit, and 2) a sandy limestone and a pebble conglomerate unit. $^{3}$ Immediately south of the power plant, the low-lying Treaty Hill exposes upper Paleozoic rocks of the Havallah Formation, which are unconformably overlain by late Cenozoic basalt flows. ${ }^{4}$ 


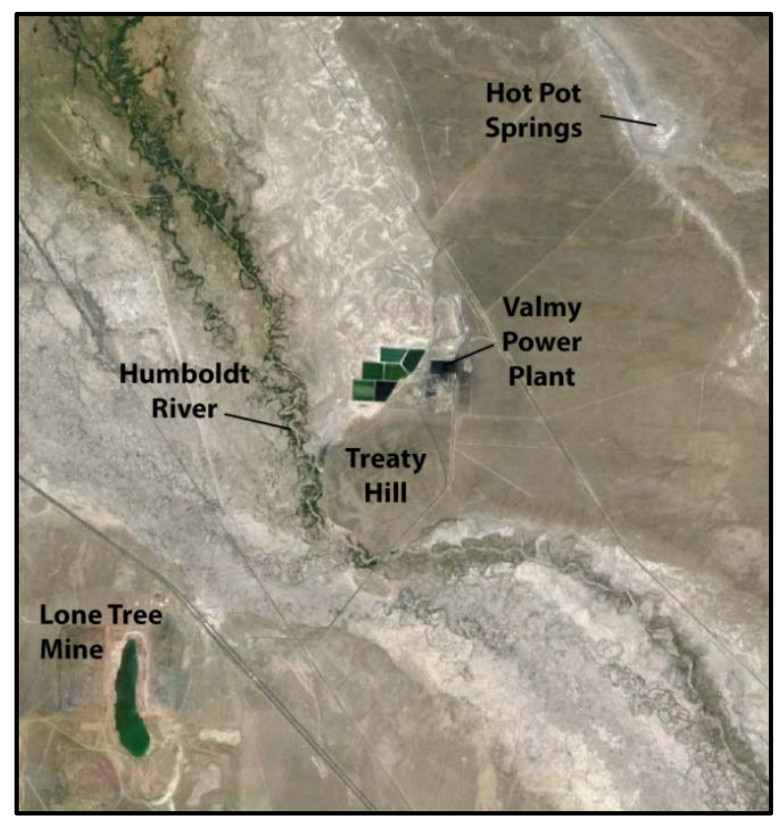

Figure 2. Map showing locations of the North Valmy power plant and other key areas discussed in this analysis.

During the Neogene, north-northwest oriented tectonic rifting led to localized volcanism and the development of extensional basins separated by mountain ranges bound by northnortheast striking normal faults. Neogene strata accumulating during and after basin development within the Humboldt River Valley likely include fluvial sandstone, lacustrine deposits, ash-rich sediments, and andesitic to basaltic lava flows. ${ }^{5}$ Neogene basin fill sediments are expected to be less than $1000 \mathrm{ft}$ at the Valmy power plant and are likely covered by a thin layer of quaternary alluvial fan and Humboldt River deposits. These Neogene sediments are a potential geothermal production target elsewhere in the basin where they occur at greater depths, but are likely too shallow to host geothermal fluids at North Valmy. At the Beowawe geothermal field, as potentially at the North Valmy plant, the Valmy Formation would be the primary geothermal reservoir target.

\subsection{Quaternary Faulting}

Quaternary faults mapped near the power plant are generally oriented north-northwest and are likely associated with active basin wide extension. ${ }^{6}$ The majority of these faults are located along the edge of the valley as range-bounding normal faults. Both north-northwest and northnortheast striking fault scarps are documented in the valley just northeast of the power plant. Although no quaternary faults have been mapped along the flank of Treaty Hill, a review of available satellite imagery reveals at least one prominent northwest facing fault scarp striking northeast that appears to offset alluvial fans along the northwest flank of the Hill. This apparent fault scarp (see Figure 3 ) is inferred to be the surface expression of a deep, northwest dipping normal fault, placing the Valmy power plant on the relative upside (i.e., footwall) block and the cooling ponds on the downthrown hanging wall. 


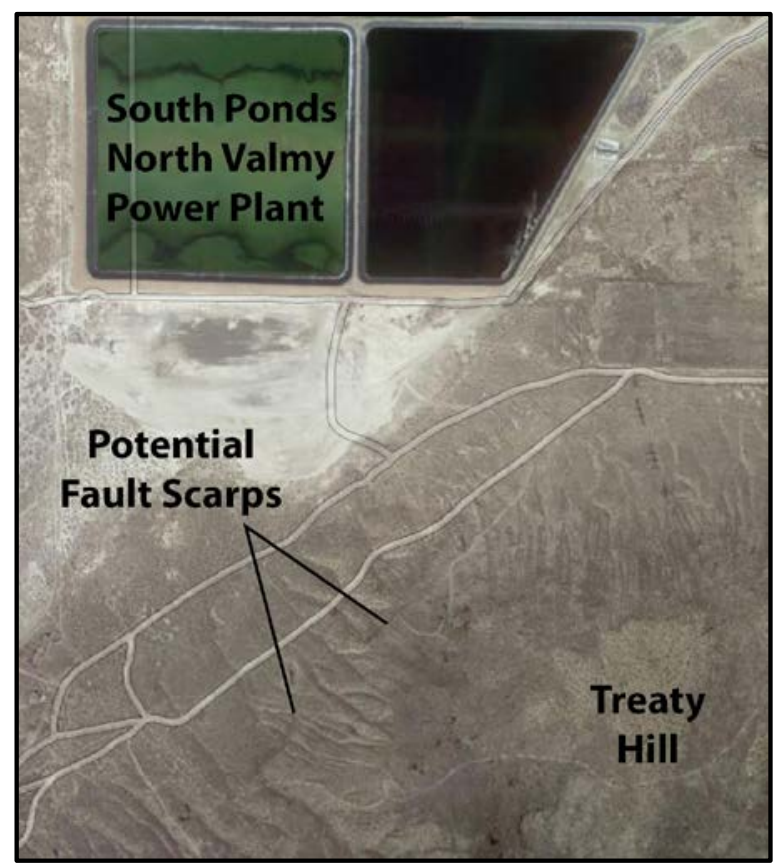

Figure 3. Location of potential Quaternary fault scarps along the northwest flank of Treaty Hill.

\subsection{Geothermal Exploration}

According to Lane et al., (2012) geothermal exploration of the Valmy area was likely initiated in the early 1970's with considerable interest in developing a resource at the nearby Hot Pot hot springs, located approximately 2 miles northeast of the power plant. During this time, the hot springs were reported to flow to the surface at $70 \mathrm{gpm}$ with recorded temperatures up to $58^{\circ} \mathrm{C} ., 7,8$ However, by the 1980 s extensive groundwater withdrawal from the Valmy power plant and dewatering activities associated with local mine operations contributed to lowering the water table and cutting off the surface flow at the hot springs. ${ }^{5}$ The current surface expressions of the dried up hot springs are defined by four travertine mounds that are large enough to be seen in the satellite image presented in Figure 1.

Recently, Oski Energy, LLC forged a renewed interest in the Hot Pot thermal anomaly and has recently pursued development of the site as The Hot Pot Project. ${ }^{5,9}$ The Hot Pot Project was initiated in 2009, when Oski acquired geothermal leases along the northeast boundary of the power plant (Figure 3), and began data compilation and initial field surveys including, gravity, soil geochemistry, and a series of six shallow $(500 \mathrm{ft}$; $150 \mathrm{~m})$ temperature gradient holes. ${ }^{5}$

Following initial investigations, Oski secured partial funding from the U.S. Department of Energy (DOE) to perform a two-dimensional seismic study across the Hot Pot area. A five line (23 mile) reflection seismic survey was conducted with the objective to utilize innovative seismic data processing, in conjunction with existing data, to identify high-potential drilling targets and to reduce drilling risk. ${ }^{5,9}$ The seismic study was successful at imaging the shallow subsurface stratigraphy above the basement, better defining the Paleozoic basement topography, and identifying deep fault structures that may serve as potential drilling targets within the 
Ordovician Valmy Formation. The Ordovician Valmy Formation is well known as a complex mixture of faulted and fractured rock that hosts a highly permeable reservoir at the Beowawe geothermal site. If the seismic study proves to be successful in identifying similar structures at depth at the Hot Pot site, then extending the seismic survey to include additional quaternary fault features that may be present near the power plant property should be considered, if additional field mapping confirms the presence of one or more faults at this location. Extrapolation (to the southwest) of the interpreted seismic cross sections presented by Lane et al. ${ }^{5}$ seem to suggest that a well drilled near the Valmy power plant might encounter as much as $1,500 \mathrm{ft}$ of upper to middle Paleozoic basement rocks at a shallow depth before encountering the fractured Ordovician Valmy Formation.

During the 1980s, Trexler et al. ${ }^{4}$ drilled a temperature gradient borehole (PVHT-5), located near the Hot Pot hot springs. The PVHT-5 boring encountered a shallow basalt flow at $120 \mathrm{ft}$ and reached a total depth in basalt of $140 \mathrm{ft}$. The temperature gradient calculated for this boring is relatively high, at $220^{\circ} \mathrm{C} / \mathrm{km}$. To better characterize the subsurface heat flow conditions at the Hot Pot site, Oski Energy drilled a series of six shallow (500 ft; $150 \mathrm{~m}$ ) temperature gradient boreholes. Well locations and contours of the calculated thermal gradients are presented in Figure $4 .{ }^{5}$ These data validate the initial findings by Trexler et al. ${ }^{4}$ and confirm that gradients greater than $9^{\circ} \mathrm{F} / 100 \mathrm{ft}\left(164^{\circ} \mathrm{C} / \mathrm{km}\right)$ exist near the center of the Hot Pot thermal anomaly. All but one of the six wells recorded temperature gradients greater than $6^{\circ} \mathrm{F} / 100 \mathrm{ft}\left(110^{\circ} \mathrm{C} / \mathrm{km}\right)$. The southernmost well (27-1), located close to 2 miles west of the power plant, recorded a gradient less than $3^{\circ} \mathrm{F} / 100 \mathrm{ft}\left(55^{\circ} \mathrm{C} / \mathrm{km}\right)$.

Given the layout of existing temperature gradient boreholes with a high gradient well to the northeast and a lower gradient well to the west, an attempt to ascertain the thermal gradient at the Valmy power plant becomes somewhat problematic and requires a better understanding of the structures controlling migration of heated fluids at depth. Based on available data, the southernmost temperature gradient borehole does not appear to be located near existing fault structures. In contrast, the Valmy power plant is located on strike with a concealed fault (Figure 5; fault C) identified from the Oski seismic survey. This concealed structure roughly aligns with the northeast extension of a possible fault scarp identified along the northwest flank of Treaty Hill. The expression of Treaty Hill above the valley floor in combination with the apparent preserved fault scarps along the northwest flank of the hill suggests that a recently active, deep rooted normal fault could be present, potentially accommodating sufficient secondary fracture permeability to allow migration of geothermal fluids to shallow levels. The inferred fault scarps, however, cannot be confirmed without direct field observations, which should be undertaken prior to extending the Oski seismic survey to cover potential quaternary fault features near the North Valmy plant. 


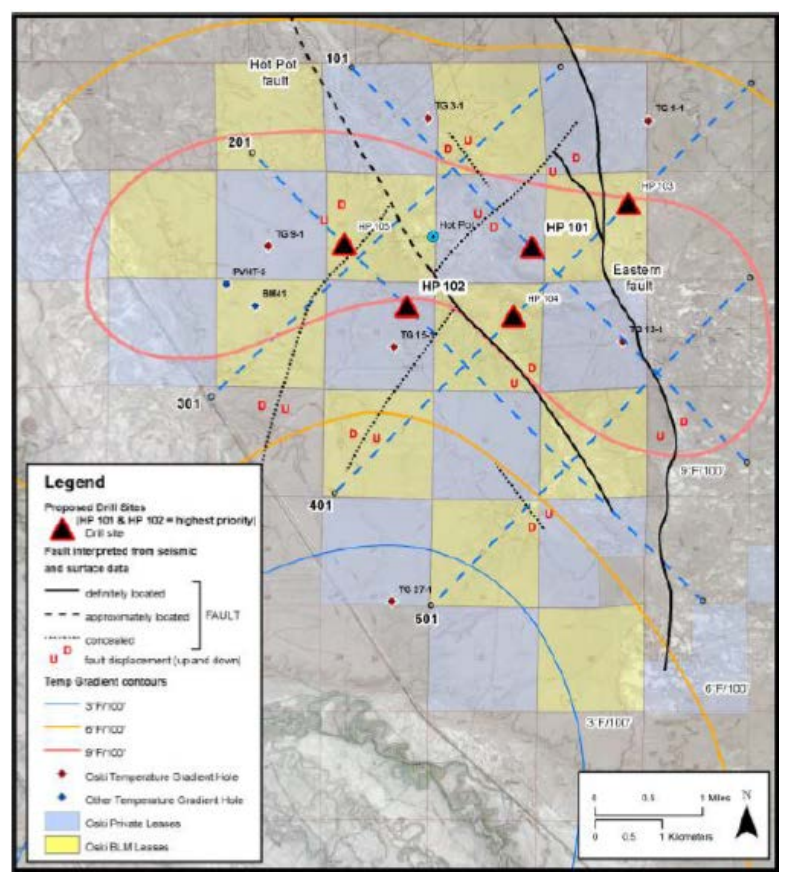

Figure 4. Temperature gradient contours and potential drilling locations at the Hot Pot project (from Lane et al. $)^{5}$

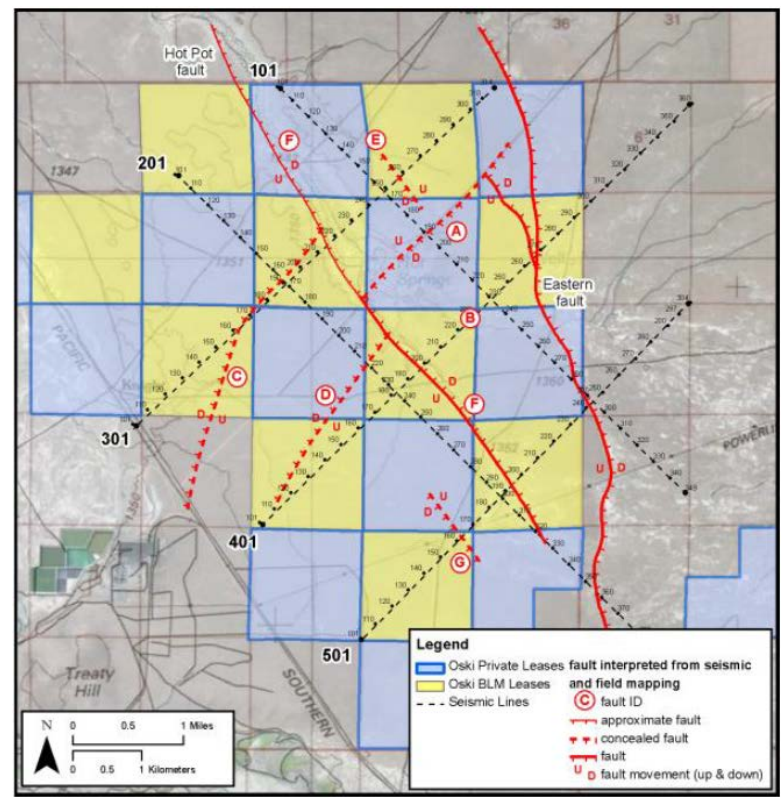

Figure 5. Location of Oski Energy, LLC geothermal leases, the Hot Pot seismic program survey lines, and interpreted structures (from Lane et al.) ${ }^{5}$

\subsection{Primary Modeling Scenarios}

In order to estimate potential drilling depths to reach a sufficient fluid temperature of $150^{\circ} \mathrm{C}$ for the various modeling scenarios, a range of conservative gradients of $4^{\circ} \mathrm{F} / 100 \mathrm{ft}\left(70^{\circ} \mathrm{C} / \mathrm{km}\right)$ to 
$5^{\circ} \mathrm{F} / 100 \mathrm{ft}\left(90^{\circ} \mathrm{C} / \mathrm{km}\right)$ were used to define Cases 1 and 2 , respectively. This resulted in drilling depths of approximately 5000 feet (Case 1 ) and 6600 feet (Case 2). Butler et al. ${ }^{10}$ reported that at the Beowawe site, which produces from the same heavily fractured reservoir of interest for this project, initial combined production from the three project wells in July 1991 was around 1.8 million $\mathrm{lb} / \mathrm{h}$, or a per-well average of $600,000 \mathrm{lb} / \mathrm{h}$. Assuming that this average rate could be replicated for new project wells at the North Valmy site, process water needs of $2.5 \mathrm{MMlb} / \mathrm{h}$ could reasonably be met using four or five production wells.

Based on work published by Shevene ${ }^{11}{ }^{11}$ that includes a review of efforts to estimate well drilling costs for geothermal projects in Nevada, we have assumed for this analysis that, in addition to five required production wells, a project would need an additional three injection wells. This is highly site-specific, but reflects a conservative interpretation of average values across the projects surveyed, and is consistent with the 2:1 ratio reported for the Beowawe site. Shevenell estimates production and injection well costs separately, ${ }^{11}$ and via relationships developed by several other authors, including Klein et al. ${ }^{12}$ Bradys ${ }^{13}$ and Augustine et al. ${ }^{14}$ The unpublished nature of the Bradys data and the much broader geographic scope of the Augustine work led to a decision in the present analysis to use the depth-based relationships presented by Klein. The Klein relationship also reflects the highest costs of the three cases presented. Resulting costs for Cases 1 and 2 using this relationship, including site-specific parameters used in developing these estimates, are shown in Figure 6.

For the two cases evaluated, average per-well costs for production wells is between $\$ 1.2 \mathrm{M}$ and $\$ 1.6 \mathrm{M}$ each, with cost variance resulting from increased depth to reach $150^{\circ} \mathrm{C}$ water in Case $2\left(70^{\circ} \mathrm{C} / \mathrm{km}\right)$ relative to Case $1\left(90^{\circ} \mathrm{C} / \mathrm{km}\right)$. A relationship was developed based on Shevenell's estimates using cost functions derived from Klein's data to estimate an adder on production well costs to account for additional costs associated with reinjection wells. Based on Shevenell's analysis of Klein's data, injection wells appear to cost about $5 \%$ more than production wells at the Beowawe site, where flow rates and drilling conditions are most likely to approximate those at North Valmy. This $5 \%$ adder was included in injection well cost estimates shown in Table 2.

Table 2. Site-specific cost parameters and resulting cost estimates for production and injection well requirements at North Valmy power plant. 


\begin{tabular}{|c|c|c|c|}
\hline & & Case 1 & Case 2 \\
\hline Avg Temp Gradient, ${ }^{\circ} \mathrm{C} / \mathrm{km}$ & & 90 & 70 \\
\hline Desired Temp, ${ }^{\circ} \mathrm{C}$ & & 150 & 150 \\
\hline Projected Drill Depth, ft & & 4,922 & 6,562 \\
\hline Per-Well Flow Rate, lb/h & & 600,000 & 600,000 \\
\hline Required Flow Rate, lb/h & & $2,500,000$ & $2,500,000$ \\
\hline Required Wells, Production & & 5 & 5 \\
\hline Required Wells, Injection & & 3 & 3 \\
\hline Production Well Costs, each & $\$$ & $1,274,394$ & $1,618,930$ \\
\hline Production Well Costs, total & $\$$ & $6,371,969$ & $8,094,651$ \\
\hline Injection Well Costs, each & $\$$ & $1,338,114$ & $1,699,877$ \\
\hline Injection Well Costs, total & $\$$ & $4,014,341$ & $\$ 5,099,630$ \\
\hline TOTAL WELL COSTS & & $10,386,310$ & $\$ 13,194,281$ \\
\hline
\end{tabular}

Within the range of expected gradients and flow rates assumed for the North Valmy site, and explicated above, total well costs for this project are likely to fall between \$10M and \$13M. However, it is important to note that these estimates are based on averages and statistical relationships. The estimates are a function of depth alone and assume average well diameters, typical drilling conditions and standard well completions.

\subsection{Sensitivity Cases}

A significant amount of uncertainty exists around the structure and source of the hydrothermal system at the Hot Pot site. While Oski's attempts to resolve this uncertainty using seismic surveys have shed light on the structural setting of the field, the lack of intermediate or deep characterization into the Valmy Formation makes it difficult to determine, with any degree of certainty, the source of the geothermal fluids expressed at Hot Pot. Identifying the best target for production at the site requires assumptions regarding the source of these fluids. If the Hot Pot field is fed by fluids transmitted via the faults imaged in the seismic surveys, then they may well contain waters from the Valmy Formation; however, the faults may also be nontransmissive, which would suggest a different source of the geothermal heat, including the possibility of convective heating. While the geothermometry data from the more recent shallow gradient wells at the site were unavailable for this study, older data published by U.S. Geological Survey (USGS) for the Hot Pot site suggests that mean reservoir temperature in the shallow field may be closer to $112^{\circ} \mathrm{C} \pm 6^{\circ} \mathrm{C}$ (USGS Circular 1978, LJP Muffler (ed)). Geothermometers used in that assessment estimate temperatures from $97^{\circ} \mathrm{C}$ (chalcedony) to $125^{\circ} \mathrm{C}$ (quartz). However, the Valmy Formation may indeed have higher temperatures than indicated by the Hot Pot estimates if there is little or no transmission of fluids between the Valmy and the shallow system feeding the Hot Pot field.

It may be possible, then, that $150^{\circ} \mathrm{C}$ geothermal fluids can be accessed in the Valmy Formation near the North Valmy plant, as modeled in the primary cases for which assumptions are discussed above. However, given the high degree of uncertainty in resource quality, it is important to understand the impact those assumptions may have on overall LCOE. For this 
reason, cases were evaluated assuming a $125^{\circ} \mathrm{C}$ fluid temperature at depths that remain quite conservative for the Valmy. Also, because flow rates have been taken from those documented for wells into the Valmy Formation at the Beowawe field, additional cases were used to evaluate the impact of a $50 \%$ decrease in per-well flow rate on overall project costs.

\subsection{Process Modeling Approach}

All simulations were performed using Aspentech: Aspen Plus ${ }^{\circledR}$ and Exchanger Design and Rating. All cost evaluations were performed using Aspentech Process Economic Analyzer (Version 8.4). ASPEN plus was used to calculate net power, heat and material balances in addition to equipment sizing and costing. The first step in the analysis was to recreate models to compare to DOE's coal-fired power plant baselines with and without CCS infrastructure. The benchmark for a subcritical pulverized coal (PC) power plant without $\mathrm{CO}_{2}$ capture is Case 9 of National Energy Technology Laboratory's (NETL) Cost and Performance Baseline for Fossil Energy Plants, Volume 1: Bituminous Coal and Natural Gas to Electricity, DOE/NETL-2010/1397. Case 10 burns much more coal to produce the same net power of $550 \mathrm{MW}$ from a subcritical PC power plant with added carbon capture infrastructure. For the sake of a direct comparison, the hybrid geothermal plant configurations were compared against both NETL Case 9 and Case 10. Both Case 9 (Figure S2) and Case 10 (Figure S3) were recreated in ASPEN Plus so that the geothermal elements could be later added (Figure S2) The recreated models both came within $1.4 \%$ of the net power projects given in the NETL report, indicating suitable validation for the current analysis. The following subsections give more detail for both Case 9 and 10 .

Case 9 is a benchmark PC plant power plant employing typical pollution control devices including a baghouse for particulate control, a selective catalytic reduction for nitrogen oxides control, and a wet flue gas desulfurization unit to control sulfur oxides. The steam cycle is a subcritical cycle with one reheat. This steam cycle is characteristic of the vast majority of operating coal plants in the United States. Steam is produced at a nominal pressure and temperature of $2400 \mathrm{psia}$ and $1050^{\circ} \mathrm{F}$; expanded through a high pressure turbine; reheated in the boiler to $1050^{\circ} \mathrm{F}$ and further expanded in intermediate pressure and low-pressure turbines to about 1 psia; where it is condensed at a saturation temperature of about $101^{\circ} \mathrm{F}$. The condensate is pumped through four feed-water heaters, deaerated and pumped through two high pressure heaters where it returns to the boiler to be generated into steam. Heat for the boiler feed water heaters comes from extracting a few percent of the steam at various pressures from the steam turbines. Low-pressure steam is used for the low-temperature condensate and higher pressure steam is required to provide the temperature difference necessary to heat higher pressure condensate. The steam cycle for Case 9 is shown in Figure S1. An ASPEN Plus simulation was developed for the steam cycle with and without geothermal heat input to boiler feed water heaters. As a result of the geothermal heating, the steam extractions are stopped, allowing this steam to flow all the way to the condenser and generate additional power.

Case 10 is another NETL benchmark PC plant as described in Case 9, albeit with installed CCS infrastructure. Case 10 represents as larger front-end boiler and steam turbine to offset the 
parasitic load associated with the CCS system, thereby netting the same output power of 550 MWe. Major infrastructure installed in Case 10 include an absorber tower, stripper column and cross exchanger and $\mathrm{CO}_{2}$ compressor pump to deliver $\mathrm{CO}_{2}$ for permanent storage. The stripper is where the $\mathrm{CO}_{2}$ capture solvent is regenerated by thermal heating $\left(120^{\circ} \mathrm{C}\right)$ adding a large heat duty of $1520 \mathrm{btu} / \mathrm{lb}$ of $\mathrm{CO}_{2}$ captured to the plant. In CCS plants, the intermediate pressure steam is taken out of the steam cycle to power the re-boiler, thus a $20 \%$ reduction in net power is observed. For this reason, the re-boiler was the focus of integration strategies. An ASPEN Plus simulation was established for the Case 10 steam cycle with varied levels of geothermal heat input at $150^{\circ} \mathrm{C}$ water. The results of the energetic and costing for Cases 9 and 10 integrations are summarized in Figure $\mathrm{S} 5$ and Figure $\mathrm{S} 6$ respectively.

The North Valmy power plant was then modeled in year two for the site-specific analysis and TEA. Efforts to contact operators at North Valmy were unsuccessful, so the team recreated the North Valmy plant in ASPEN Plus using publically available information. Information on North Valmy was taken from the US Energy Information Administration (EIA) filings 923 and 860 from www.ElA.gov. Filing 923 provided detailed electric power data, both monthly and annually on the electricity generation, fuel consumption, fossil fuel stocks, and receipts at the power plant and prime mover level. Filing 923 also provided more detailed information such as fuel receipts and costs, generator data such as generation, fuel consumption and stocks, fossil fuel stocks, non-utility source and disposition of electricity and all relevant environmental data. Filing 860 contained detailed information regarding the company, facility, unit type, service dates, energy sources, heat content, nameplate capacity and capacity for summer and winter months. All other information needed for recreating the North Valmy plant in ASPEN plus was gathered from the NETL Cost and Performance Baseline for Fossil Energy Plants, Volume 1: Bituminous Coal and Natural Gas to Electricity, DOE/NETL-2010/1397 and Black and Veatch; Power Plant Engineering: Babcock \& Wilcox; Steam: Cheremisinoff; Cooling Towers. Other information was collected from the Class I application review title $V$ Facility-wide operating permit for Sierra Pacific Power CO. North Valmy Generating Station AP4911-0457; from the State of Nevada Department of Conservation and Natural Resources, Division of Environmental Protection Bureau of Air Quality, July 9, 2007.

North Valmy is a PC-fired power plant located in a high desert environment in north central Nevada. The plant has two units that burn low sulfur bituminous and subbituminous coal at an elevation of approximately 4,300 ft in north central Nevada, producing a maximum of $522 \mathrm{MW}$ though annual averages are lower than nameplate capacity (315MW in 2014). North Valmy's two boilers are wall-fired, run PC, with a dry ash system, using a subcritical steam cycle to generate power. Unit 1, operational since December 1981, is a Babcock and Wilcox unit with nameplate of $277.2 \mathrm{MW}$ and seasonal capacity of $254 \mathrm{MW}$. Unit 2 has been operational since May 1985 and is a Foster Wheeler unit with nameplate of $289.8 \mathrm{MW}$ and seasonal capacity of $268 \mathrm{MW}$. The plant has two steam turbine generator sets both of which are assumed to be subcritical from their reported heat rates (10,935 Btu/kWh, 31.2\% efficiency). In 2014 the Average Generation (EIA) for Units 1 and 2 are $175 \mathrm{MW}$ and $140 \mathrm{MW}$, respectively. 
Groundwater from a nearby mining operation is used at least in part as makeup for mechanical cooling towers. The cooling tower blowdown is delivered to 158 acres of evaporation ponds for disposal. The estimated consumption at rated output of $522 \mathrm{MW}$ is 3,227 million gallons per year with $>150$ million gallons per year of evaporation from the ponds is required (Figure 7).

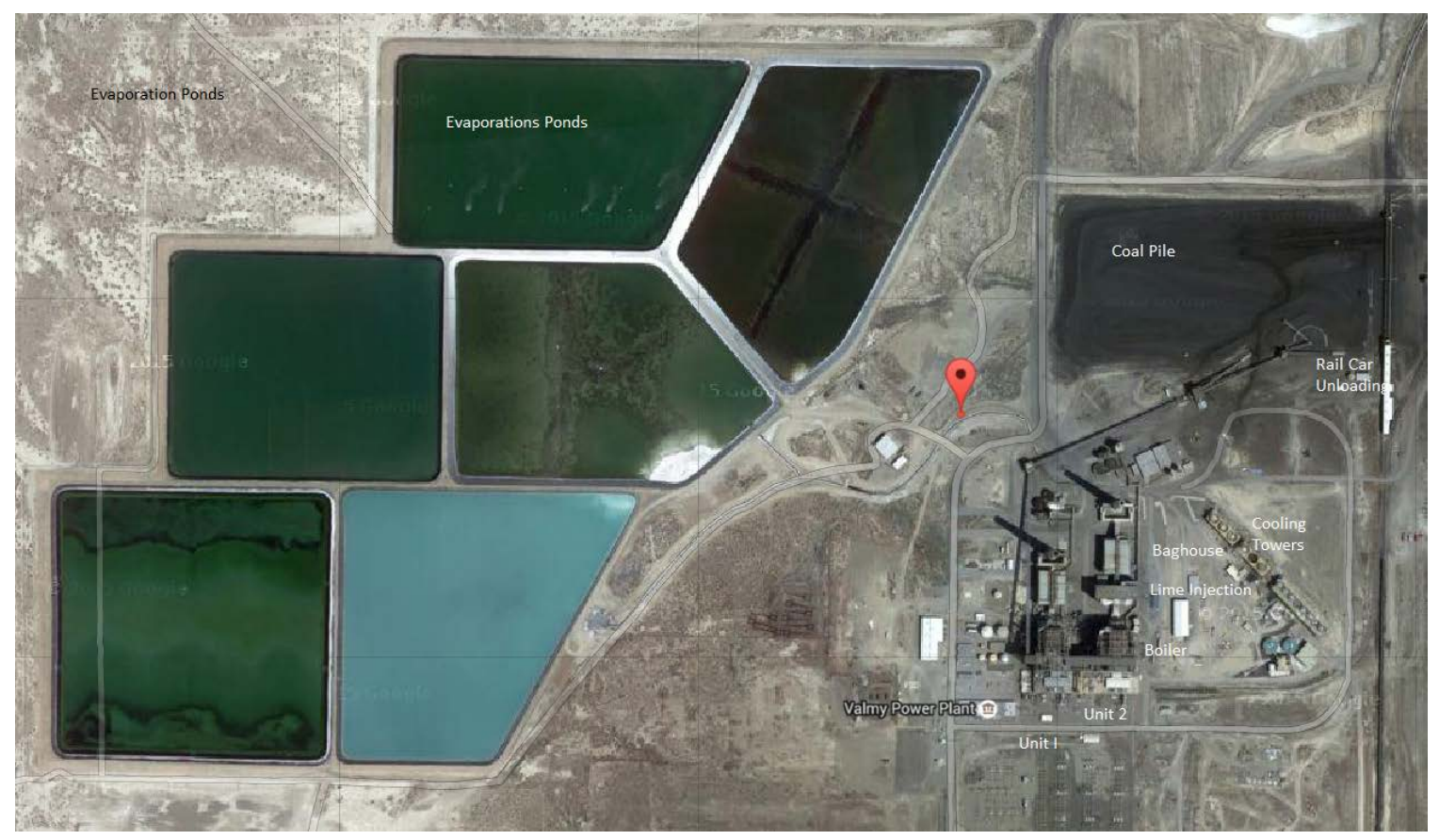

Figure 6. North Valmy power plant layout as shown from Google Maps.

Simulations were conducted under a set of site condition assumptions. Site atmospheric conditions used for the analysis were taken from Winnemucca Nevada airport National Oceanic and Atmospheric Administration's 2010 10-year climate normals (46 miles from North Valmy). From this data we set a 12.59 psia ambient pressure and a 1.5 psia condenser pressure. Condenser water is assumed to be $84.2^{\circ} \mathrm{F}$ at the inlet and $104.2^{\circ} \mathrm{F}$ at the outlet, with a $10^{\circ} \mathrm{F}$ approach temperature. After the analysis was completed, a restriction in the NV environmental permit was discovered that limits North Valmy cooling water circulation to $2 \times 80,200$ gallons per minute. In this study a higher circulation rate of 283,000 is assumed.

\subsection{Simulations of Geothermal Boiler Feed Water Heating at North Valmy}

Compared to the earlier study, which evaluated the integration of this hybrid approach with the NETL Case 9 benchmark with $150^{\circ} \mathrm{C}$ geothermal water, North Valmy's nameplate capacity is less than Case 9 (522 MW vs. $550 \mathrm{MW}$ ) and the steam cycle is less efficient (31.2\% vs. 36.8\%). As a consequence, the steam flow rate and condenser duty is higher for North Valmy. For all simulations, the geothermal water resource is assumed to be the same 2,695,600 lb/hr flow rate as used in the Case 9 and 10 simulations from the previous year's report. The Case 9 and Case 10 baselines represent hypothetical cases using an assumed $150^{\circ} \mathrm{C}$ resource temperature, while 
the North Valmy simulations use the resource-limited $125^{\circ} \mathrm{C}$. The lower temperature of the geothermal source in the North Valmy-specific analysis limits the boiler feed water heating to the first three heaters instead of all four low-pressure heaters. It should also be noted that the higher estimated steam flow at North Valmy reduces the condensate fraction that can be heated by the geothermal source to $80 \%$. The remaining $20 \%$ is heated in the existing boiler feed-water heaters with extraction steam. The cooled $\left(123^{\circ} \mathrm{F}, 51.6^{\circ} \mathrm{C}\right)$ geothermal water is reinjected into the formation for reheating. Here, $80 \%$ of the steam previously extracted produces additional power flowing through the low-pressure turbine to the condenser, increasing the condenser duty by the additional amount of steam condensed (2830 MMBTUH to 3200 MMBTUH).

For this analysis we have modeled heating the boiler feed water using a plate and frame exchanger instead of the shell and tube exchangers typically used as boiler feed water heaters. The initial cost is roughly half a shell and tube cost because the heat transfer coefficient is much higher and a single exchanger can meet the total duty. A single exchanger is assumed as cleaning would be done in normal outages, or the load switched to the existing feed water heaters for cleaning during plant operation. Further, fouling (from scaling) is typically about half that of a shell and tube exchanger.

As explained in Section 4, hot springs were present in the 1970s and subsequent water withdrawal from the North Valmy Power Station and Lone Tree Mining Operations resulted in a drop in the water table and ceased spring flow in the Hot Pot area. Because of its potential to preserve groundwater for other uses, dry cooling was investigated for North Valmy.

Simulations examining combined use of both the air cooler and the existing mechanical draft cooling towers suggest that this combination is sufficient to maintain a 1.5 psia condenser pressure. The projected water savings are very large (Table 3 ). In this case, the cooling tower is used 2,090 hours compared to the 8,760 hours of the current cooling, with approximately $9 \%$ of the makeup required for full wet cooling and $7 \%$ of the water delivered to the evaporation ponds.

Table 3. Comparison of water use for All Wet and Wet/Dry Cooling

\begin{tabular}{|r|c|r|r|r|}
\hline All Wet Cooling & Makeup & Evaporation & Blowdown & \multicolumn{1}{c|}{ Drift } \\
\hline $\mathrm{lb} / \mathrm{hr}$ & $3,072,040$ & $2,688,042$ & 143,153 & 240,852 \\
\cline { 3 - 5 } $\mathrm{lb} / \mathrm{yr}$ & $2.69 \mathrm{E}+10$ & $2.36 \mathrm{E}+10$ & $1.25 \mathrm{E}+09$ & $2.11 \mathrm{E}+09$ \\
\cline { 2 - 5 } MMgal/yr & 3,227 & 2,823 & 150 & 253 \\
\hline Wet/Dry Cooling & Makeup & Evaporation & Blowdown & \multicolumn{1}{c|}{ Drift } \\
\hline $\mathrm{lb} / \mathrm{hr}$ & 275,551 & 241,106 & 10,712 & 23,732 \\
\cline { 3 - 5 } $\mathrm{lb} / \mathrm{yr}$ & $2.41 \mathrm{E}+09$ & $2.11 \mathrm{E}+09$ & $9.38 \mathrm{E}+07$ & $2.08 \mathrm{E}+08$ \\
\cline { 3 - 5 } MMgal/yr & 289 & 253 & 11 & 25 \\
\cline { 2 - 6 } all wet & $8.97 \%$ & $8.97 \%$ & $7.48 \%$ & $9.85 \%$ \\
\hline
\end{tabular}

${ }^{*}$ Circulation rate for both cases is $160,667,782 \mathrm{lb} / \mathrm{hr}\left(84.2^{\circ} \mathrm{F}\right.$ to $\left.104.2^{\circ} \mathrm{F}\right)$. 
Dry-cooling systems were modeled in ASPEN Plus using the concept in the U.S. Department of Energy: Advanced Research In Dry-Cooling (Arid); Funding Opportunity No. DE-FOA-0001197; 26-Sep-14. The power plant steam condenser pressure was assumed to be maintained at the $1.5 \mathrm{psia}$ used for the general analysis. The air cooler is arbitrarily designed for $64^{\circ} \mathrm{F}$ ambient air temperature which is estimated by 10 -year climate averages to be $76 \%$ of the hours in the year near North Valmy as shown in the figure below. Optimization of the air temperature was not performed, but optimization of airflow around the design temperature of $64^{\circ} \mathrm{F}$ was performed (Supplementary Tables). Sizing the air cooler for a $74^{\circ} \mathrm{F}$ ( $86 \%$ of the year average temperature) was found to require an exchanger nearly four times as large. Dry cooling at $64^{\circ} \mathrm{F}$ requires an exchanger of approximately 112 acres, which is less than the 158 acres of evaporation ponds currently in use.

The combination of the air cooler and the existing mechanical draft cooling towers was simulated and easily found to keep the cooling water temperature low enough to maintain a 1.5 psia condenser pressure. The projected water savings are very large.

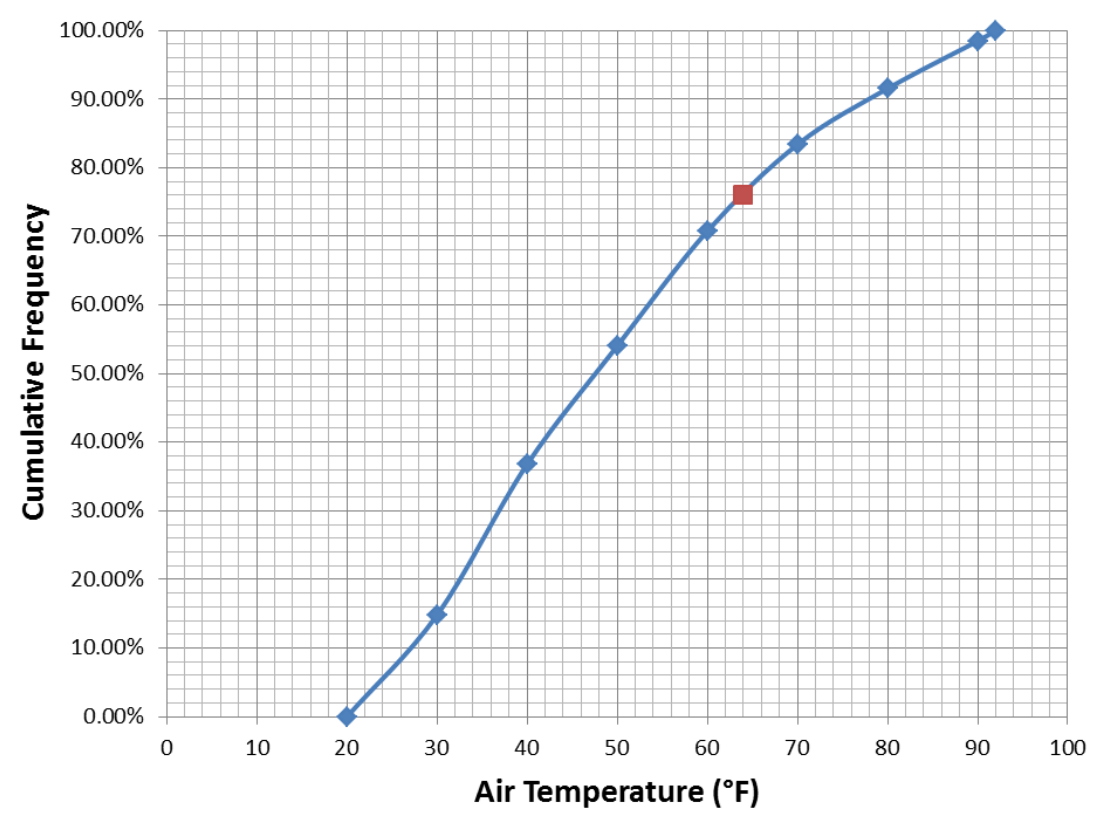

Figure 7. Cumulative air temperature frequency in Winnemucca, Nevada

Over the course of the National Oceanic and Atmospheric Administration's normal year previously mentioned and at the nameplate capacity of $522 \mathrm{MW}$, the cooling tower is used 2090 hours with only about $9 \%$ of the makeup required for full wet cooling and only about $7 \%$ of the water delivered to the evaporation ponds.

An alternative to the wet/dry cooling discussed above is to use the geothermal heat for lithium bromide absorption refrigeration or use the additional power produced by the geothermal boiler feed water heating to provide ammonia mechanical refrigeration. The refrigeration produced would then be used to cool the water coming from the air cooler prior to its entry into the condenser. A 24-hour cycle of the highest normal temperature day was run for 
each of the absorption and mechanical refrigeration cases and it was found that the cooling water temperature could not be maintained at the desired level. The system flow diagrams are shown as the last two supplementary figures.

A number of caveats are worth noting in understanding the cases modeled under this effort. Owing to both its low-rank fuel and low process efficiency, the North Valmy plant's flue stream is better reflected in the NETL Case 9 than Case 10, but it should be noted that Case 9 underestimates both the volume of flue gas and the mass of $\mathrm{CO}_{2}$ reflected by a simple capacitybasis comparison. As such, the re-boiler duty calculations are compared to Case 9 rather than Case 10 (Table 3). The low efficiency of the plant requires relatively more re-boiler duty and a higher degree of $\mathrm{CO}_{2}$ capture than for a comparably sized Case 9. It is also possible that the lack of a wet flue gas desulfurization system at North Valmy may require additional cooling for the direct contact cooler, and greater SOx removal than is required under Case 9. Also, the low temperature of the geothermal resource, assumed here to be $125{ }^{\circ} \mathrm{C}$, provides less heat duty than would be provided by a higher temperature resource. However, for an advanced carbon capture system with far lower re-boiler temperature requirements $\left(\sim 70^{\circ} \mathrm{C}\right)$, applying the geothermal resource to the re-boiler and doing some boiler feed water heating with the residual energy. The results are described in the table below. As seen in Table 4, assuming the same 2.7 MMlb water per hour, Case 9 would utilize the $150^{\circ} \mathrm{C}\left(302^{\circ} \mathrm{F}\right)$ resource from the first year's study, resulting in $361 \mathrm{MMBtu}$, which is $22.5 \%$ of the re-boiler duty for the plant. Similarly, at Valmy, a $125^{\circ} \mathrm{C}\left(257^{\circ} \mathrm{F}\right)$ resource would be able to provide nearly $240 \mathrm{MMbtu}$, which is $12.1 \%$ of the re-boiler duty. It should be noted that while the flue gas composition is closer to Case 9 , the formal TEA analysis for hybrid Carbon Capture cases in the subsequent sections could only be provided for a hypothetical DOE Case 10 base line as it is the only baseline with costs available for comparison.

Table 3. Hybrid direct-use geothermal $125^{\circ} \mathrm{C}$ water providing carbon capture solvent re-boiler duty

\begin{tabular}{|c|c|c|c|}
\hline \multicolumn{4}{|c|}{ Geothermal Resource as Partial Reboiler Duty Supply } \\
\hline & & Case 9 ** & North Valmy \\
\hline Geothermal Water flow & $\mathrm{Ib} / \mathrm{hr}$ & $2,695,600$ & $2,695,600$ \\
\hline Flue Gas estimate & $\mathrm{lb} / \mathrm{hr}$ & $5,043,963$ & $6,031,228$ \\
\hline $90 \%$ CO2 removal & $\mathrm{lb} / \mathrm{hr}$ & 934,828 & $1,154,801$ \\
\hline Geothermal water T. in & ${ }^{\circ} \mathrm{F}$ & 302 & 257 \\
\hline Geothermal water T out & ${ }^{\circ} \mathrm{F}$ & 168 & 168 \\
\hline Q available & MMBtu & 361.2 & 239.9 \\
\hline Estimated $\mathrm{Q}$ required * & MMBtu & 1,605 & 1,983 \\
\hline$\%$ of duty from geothermal & & $22.5 \%$ & $12.1 \%$ \\
\hline \multicolumn{4}{|c|}{ * Reboiler Duty assumed proportional to $\mathrm{CO} 2$ removed } \\
\hline \multicolumn{4}{|c|}{ ** Case 9 represents a $550 \mathrm{MW}$ retrofit to $\mathrm{CO} 2$ capture with } \\
\hline \multicolumn{4}{|c|}{ comparable flue gas flow to North Valmy } \\
\hline \multicolumn{4}{|c|}{ Assumption: Advanced Carbon capture system $-70^{\circ} \mathrm{C}\left(158^{\circ} \mathrm{F}\right)$, } \\
\hline \multicolumn{4}{|c|}{$10^{\circ} \mathrm{F}$ geothermal water approach $\left(168^{\circ} \mathrm{F}\right)$} \\
\hline
\end{tabular}




\subsection{Energy and Economic Projections}

The energy and cost of electricity projections for all cases modeled in Aspen Plus are tabulated in Tables 5-8. The classes of cases are broken out by type: No Carbon Capture, North Valmy Cases, and With Carbon Capture. For each class of cases there is a reference case provided by recreating NETL's Case 9 (subcritical plant without $\mathrm{CO}_{2}$ capture), site-specific North Valmy, and then Case 10 (subcritical with $\mathrm{CO}_{2}$ capture). For the No Carbon Capture cases, we modeled cases for the boiler feed water heating and using the same geothermal resource through an ORC for comparison. With North Valmy, we provide the same boiler feed water heating study but the similar ORC simulation was not performed due to its higher cost and lower power output. The other North Valmy cases investigate dry-cooling cases where air fans could provide the majority of cooling to the plant and save $91 \%$ of the plant's water consumption. Valmy may save an estimated 2.9 billion gallons per year, more water than is used for domestic consumption by the residents of the State of Nevada in a week. ${ }^{15}$ The last cases are with Carbon Capture, Case 10 with an amine baseline at two levels of boiler duty provided by geothermal resources. It should be noted that all carbon capture models were done based on Case 10 as it is the only benchmark-configured process to be used for analysis. As such, the last two With Carbon Capture cases look at more advanced carbon capture solvents such as $\mathrm{CO}_{2} \mathrm{BOLs}$ used in place of MEA. We could not model North Valmy with amine-based Carbon Capture due to heat transfer requirements. The re-boiler temperature requires $130^{\circ} \mathrm{C}$ water, which is above the $125^{\circ} \mathrm{C}$ best case resource viability at Valmy. For the advanced solvents a $75^{\circ} \mathrm{C}$ water could be provided and would provide a similar benefit as the Case 10 hybrid analysis. It should be noted that these simulations assume that all hybrid plants are operated virtually identical to their reference case, whether Case 9, North Valmy or Case 10 albeit with geothermal infrastructure auxiliary draws and capital costs and resource extraction costs. 
Table 4. Net electric power and fuel cost estimates for each model case

\begin{tabular}{|c|c|c|c|c|c|c|c|c|c|c|c|c|c|c|c|c|}
\hline \multirow[b]{2}{*}{ Fuel Costs } & \multicolumn{3}{|c|}{$\begin{array}{l}\text { Mo Ciabon Capture } \\
\text { (NeflL Gase } 9 \text { reference: Subritizal PC) }\end{array}$} & \multicolumn{4}{|c|}{ No Ganon Capture } & \multicolumn{3}{|c|}{ Morth Valmy Cases Subcritical PC } & \multicolumn{5}{|c|}{$\begin{array}{l}\text { With Carbon Capture } \\
\text { (Gase } 10 \text { reference: Subcritical PC with MEA Capture solvent) }\end{array}$} & \multirow[b]{2}{*}{$\begin{array}{l}\text { Assumption } \\
\text { fist betow) }\end{array}$} \\
\hline & $\begin{array}{c}\text { Merl Gase } 9 \\
\text { brsefine } \\
\text { reference case }\end{array}$ & $\begin{array}{c}\text { Case } 9 \\
\text { basefine with } \\
\text { geothennal } \\
\text { for BFw } \\
\text { hesting }\end{array}$ & $\begin{array}{c}\text { Case } 9 \\
\text { basefine wf } \\
\text { geothennal } \\
\text { for brw. } \\
\text { through ork } \\
\text { first }\end{array}$ & $\begin{array}{l}\text { Worth Valmy } \\
\text { basefine }\end{array}$ & $\begin{array}{c}\text { Morth Valny } \\
\text { basefine w/ } \\
\text { geothenal } \\
\text { for BFw 1300 } \\
\text { gpan }\end{array}$ & 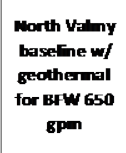 & $\begin{array}{l}\text { Morth Vilny } \\
\text { basefine w/ } \\
\text { geothernal } \\
\text { for BFW } 1300 \\
\text { gpen } 2 \text { X Welts }\end{array}$ & $\begin{array}{c}\text { Worth Vityy } \\
\text { basefine w/ } 64 \\
\text { F it coofing } \\
\text { no geothermal }\end{array}$ & 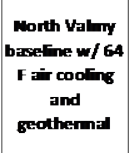 & 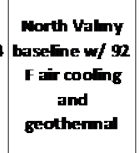 & $\begin{array}{l}\text { Cise } 10 \text { Only } \\
\text { (recrested) }\end{array}$ & $\begin{array}{l}\text { Cres } 10 \text { with } \\
\text { geothennal } \\
\text { for BFW, but } \\
\text { for } 7 \% \text { of } \\
\text { reboler first }\end{array}$ & $\begin{array}{l}\text { Crse } 10 \text { with } \\
\text { geothennal } \\
\text { for } B F W \text {, but } \\
\text { for } 100 x \text { of } \\
\text { reboiler first }\end{array}$ & $\begin{array}{l}\text { Case } 10 \text { with } \\
\text { low viscosity } \\
\text { co2Bots } \\
\text { solvent vs } \\
\text { meEA (no } \\
\text { geothermal) }\end{array}$ & 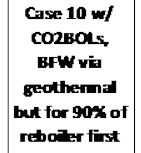 & \\
\hline TOTAL (STEAM TURBINE) POWER, KWe & 574,331 & 597,822 & 588,505 & 553,418 & 565,302 & 559,572 & 565,302 & 553,418 & 565,302 & 565,302 & 668,950 & 695,453 & 830,588 & 760,890 & 807,486 & 1 \\
\hline Portion of Total Power from ORC, $\mathrm{kWe}$ & & & 15,767 & & & & & & & & & & & & & \\
\hline \multicolumn{17}{|l|}{ AUXIUARY LOAD SUMMARY, kWe } \\
\hline Coal Feed, Boiler and Auxitiaries & 21,360 & 21,360 & 21,360 & 21,112 & 21,112 & 21,112 & 21,112 & 21,112 & 21,112 & 21,112 & 30,470 & $30,4 \pi 0$ & 30,470 & 30,470 & 30,470 & 5 \\
\hline $\mathrm{CO} 2$ Copture Plant Auxilianies & & & & & & & & & & & 19,231 & 19,268 & 19,584 & 27,660 & 19,584 & 1 \\
\hline CO2 Compression & & & & & & & & & & & 48,790 & 48,790 & 48,790 & 48,790 & 48,790 & 9 \\
\hline Condensate Pumps & 516 & 514 & 512 & 556 & 674 & 680 & 674 & 556 & 674 & 674 & 405 & 432 & 723 & 405 & 707 & 1 \\
\hline Groulating Woter Pumps & 4,963 & 5,844 & 5,896 & 5,825 & 6,427 & 6,103 & 6,427 & 5,83 & 6,427 & 6,427 & 10,199 & 10,984 & 14,221 & 10,199 & 13,486 & 5 \\
\hline Ground Water Pumps & 540 & 636 & 641 & 366 & 406 & 261 & 406 & & N/A & 282 & 930 & 1,001 & 1,296 & 930 & 1,229 & 1 \\
\hline Cooling Tower Fans & 2,770 & 3,262 & 3,291 & 1,869 & 2,031 & 1,928 & 2,031 & & & 1,411 & 7,791 & 8,383 & 10,854 & 7,791 & 10,293 & 1 \\
\hline Transformer Loss & 1,804 & 1,878 & 1,848 & 1,716 & 1,752 & 1,735 & 1,752 & 1,716 & 1,52 & 1,752 & 2,337 & 2,429 & 2,901 & 2,337 & 2,821 & $\mathbf{1}$ \\
\hline Air Cooler Fans & & & & & & & & 10,280 & 10,280 & 10,280 & & & & & & \\
\hline Geothermal Well Injertion Pumps & & 3,039 & 3,039 & & 779 & 389 & $7 / 9$ & & 799 & $7 m$ & & 3,039 & 50,879 & & 7,954 & 1 \\
\hline TOTAL AUXIHARIES, KWe & 31,953 & 36,532 & 36,587 & 31,444 & 33,181 & 32,208 & 33,181 & 39,489 & 41,024 & 42,717 & 120,152 & 124,796 & 179,718 & 128,581 & 135,3 & 2 \\
\hline NET POWER, kWe & 542,379 & 561,289 & 551,918 & 521,95 & 532,120 & 527,365 & 532,120 & 513,929 & 524,277 & 522,584 & 548,799 & 570,657 & 650,870 & 632,309 & 672,153 & 2 \\
\hline Net Plant Efficiency (HHV) & $36.3 \%$ & $37.5 \%$ & 36.96 & 31.46 & $30.1 \%$ & $20.8 \%$ & $30.1 \%$ & $30.9 \%$ & $29.6 \%$ & $29.5 \%$ & $26.1 \%$ & $27.1 \%$ & $310 \%$ & $30.1 \%$ & $320 \%$ & 2 \\
\hline Net Plant Heat Rate (Btu/kWh) & 9,408 & 9,091 & 9,245 & 10,935 & 11,355 & 11,457 & 11,355 & 11,049 & 11,525 & 11,562 & 13,074 & 12,573 & 11,023 & 11,347 & 10,674 & 2 \\
\hline As-Reoeived Cnal Feed (kg/h) & 198,391 & 198,391 & 198,391 & 247,217 & 247,217 & 247,217 & 247,217 & 247,217 & 247,217 & 247,217 & 278,956 & 278,956 & 278,956 & 278,956 & 278,956 & 5 \\
\hline Thermad Input, kWt & $1,495,379$ & $1,495,379$ & $1,495,379$ & $1,663,737$ & $1,770,324$ & $1,770,324$ & $1,770,324$ & $1,663,737$ & $1,770,324$ & $1,770,324$ & $2,102,643$ & $2,102,643$ & $2,102,643$ & $2,102,643$ & $2,102,643$ & 5 \\
\hline Total $(\mathrm{CO}$ Production Rate (kg/A) & 471,116 & 471,116 & 471,116 & 581,971 & 581,971 & 581,971 & 581,971 & 581,971 & 581,971 & 581,971 & 695,954 & 695,954 & 695,954 & 695,954 & 695,954 & 5 \\
\hline Percent CO2 Captured & $0 x$ & $0 \%$ & $0 x$ & ox & $0 x$ & $0 \%$ & $0 \%$ & ox & $0 \%$ & $0 \%$ & $90 \%$ & $90 \%$ & $90 \%$ & $90 \%$ & $90 \%$ & 5 \\
\hline Geothermal Water How (lb/hr) & $\mathbf{0}$ & $2,695,600$ & $2,695,600$ & & $2,695,600$ & $1,347,800$ & $2,695,600$ & & $2,695,600$ & $2,695,600$ & $\mathbf{0}$ & $2,695,600$ & $37,000,000$ & $\mathbf{0}$ & $10,000,000$ & $\mathbf{1}$ \\
\hline Total Geothermal Duty (MMBtu/hr) & $\mathbf{0}$ & 517 & 517 & & 517 & 517 & 517 & & 517 & 517 & $\mathbf{0}$ & 517 & $2,5 \pi$ & $\mathbf{0}$ & 1,605 & $\mathbf{1}$ \\
\hline Arrubal Fuel Cost (\$MM/year) & $\$ 622$ & $\$ 622$ & $\$ 622$ & $\$ 80.4$ & $\$ 80.4$ & $\$ 80.4$ & $\$ 80.4$ & $\$ 80.4$ & $\$ 80.4$ & $\$ 80.4$ & $\$ 87.4$ & $\$ 87.4$ & $\$ 87.4$ & $\$ 87.4$ & $\$ 622$ & 2 \\
\hline Utikization Factor & $85 \%$ & $85 \%$ & $85 \%$ & $85 \%$ & $85 \%$ & $85 \%$ & $85 \%$ & $85 \%$ & $85 \%$ & $85 \%$ & $85 \%$ & $85 \%$ & $85 \%$ & $85 \%$ & $85 \%$ & 5 \\
\hline Fuel Cost (C/kWe hr) & 1.54 & 1.49 & 151 & 207 & 203 & 205 & 203 & 210 & 206 & 207 & 214 & 206 & 1.80 & 186 & 1.24 & 2 \\
\hline
\end{tabular}

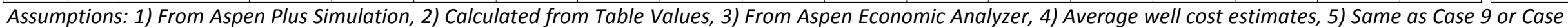

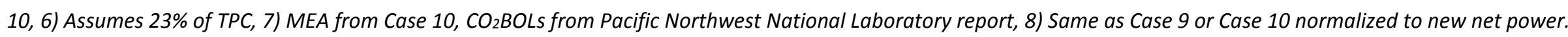




\subsubsection{No Carbon Capture Cases}

The first three cases in Table 3 represent the cases modeled for a generic subcritical coalfired power plant. The first case is the recreation of NETL's Case 9 baseline to validate the simulations using ASPEN Plus. The second case in Table 3 represents the use of geothermal water for preheating the boiler feed water in Case 9. Here geothermal water at $150^{\circ} \mathrm{C}$ and a flow rate of 2,695,600 lb/hr is used, resulting in an estimated net power increase of $19 \mathrm{MWe}$. The third case represents the conditions as the second case, but with the geothermal water first passing through an i-butane-based ORC system. Here, only a $10 \mathrm{MWe}$ increase in net electric power is predicted due the low efficiency of the $\mathrm{ORC}$ at $150^{\circ} \mathrm{C}$, and the lower grade heat of the resulting water for boiler feed water preheating. Two other ORC cases were modeled using ammonia and propane, but the net electric power increase was even lower than i-butane. This comparison indicates that direct use of the geothermal water into the steam cycle feed water heater provides the highest power output compared to an ORC integration.

\subsubsection{North Valmy Site-Specific Cases}

The middle five cases in Table 3 outline all site-specific simulations of North Valmy with boiler feedwater heating, with varied parameters for dry cooling. The boiler feedwater hybrid case for North Valmy uses 2.7 million $\mathrm{lb} / \mathrm{hr}$ of $125^{\circ} \mathrm{C}$ water, and results in a $10.1 \mathrm{MW}$ capacity increase over the base North Valmy case, at a total capital cost of $26.5 \mathrm{M}$ USD. The lower temperature flow produces $8.9 \mathrm{MW}$ less power than Case 9 with $150{ }^{\circ} \mathrm{C}$ boiler feedwater heating as only three of the heaters can be replaced at $125^{\circ} \mathrm{C}$ rather than four heaters at $150{ }^{\circ} \mathrm{C}$. A power comparison for a stand alone ORC was not performed with $125{ }^{\circ} \mathrm{C}$ water as net power would be similarly low as Case 9 with ORC, albeit with a higher capital cost. Halving the flow available at Valmy $\left(1,347,800 \mathrm{lb} / \mathrm{hr}\right.$ at $\left.125^{\circ} \mathrm{C}\right)$, results in $5.4 \mathrm{MW}$ of capacity. The reduced flow as expected produces a little more than half of the power of the higher flow rate. Separate economic assessments of the reduced flow are described in section 6 .

The remaining three cases evaluate a novel approach to reduce ground water use by up to 2.9 billion gallons per year at North Valmy. Here a dry-cooling system was modeled for three cases, the first two assuming $64^{\circ} \mathrm{F}$ ambient temperatures, with and without geothermal integration. The third case uses a hypothetical $92^{\circ} \mathrm{F}$ ambient air case where a wet- and drycooling system could be implemented, with wet cooling used only in the summer months. Here, the addition of air-cooling represents an $8 \mathrm{MW}$ auxiliary draw to the plant. Using geothermal with the dry cooling enables $10.3 \mathrm{MW}$ more power, bringing the hybrid dry-cooling/geothermal system up a net 2.3 MW over the recreated North Valmy system. Thus, a geothermal hybrid design could more than power the dry-cooling system, potentially saving 2.9 billion gallons of groundwater per year. The last Valmy case considers a combined wet- and dry-cooling system that operates dry $75 \%$ of the year. With geothermal integration, this system could provide 0.6 $\mathrm{MW}$ of additional capacity, while consuming only $7 \%$ of the cooling water. Projected costs and auxiliary power draw as a function of airflow were performed in ASPEN Economic Analyzer. The 
amount of airflow (500 MMlb/hr) was set based on the lowest of the capital expenditures of $\$ 48$ $M$ USD for 20 cooling fans.

\subsubsection{With Carbon Capture Cases}

The remaining cases in Table 3 represent a generic coal-fired power plant with $\mathrm{CO}_{2}$ capture. The first two reference a recreation of Case 10, which is based on amine-based (MEA) carbon capture and sequestration. The fifth case shows the same geothermal water flow as the two earlier cases $(2,695,600 \mathrm{lbs} / \mathrm{hr})$ is estimated to provide $7 \%$ of the MEA re-boiler duty in addition to providing heat to the first four steam cycle feed-water heaters. This integration strategy results in an estimated $21 \mathrm{MWe}$ of net power over Case 10. The sixth case is similar but considers as much larger geothermal source $(37,000,000 \mathrm{lbs}$ per $\mathrm{hr})$ in order to supply $100 \%$ of the MEA re-boiler duty. Although this geothermal water rate is deemed infeasible, the net power projections in this case suggest potential for $101 \mathrm{MWe}$ net output increase over Case 10.

The final two modeling cases in Table 3 evaluate the $\mathrm{CO}_{2} \mathrm{BOLs}$ advanced solvent platform. The $\mathrm{CO}_{2} \mathrm{BOLs}$ solvent has a much lower projected regeneration temperature and would, therefore, potentially be more amenable to lower grade geothermal resources. Indeed, the last case in Table 3 shows that $10,000,000 \mathrm{lbs} / \mathrm{hr}$ of geothermal water (at $150^{\circ} \mathrm{C}$ ) could potentially be used to offset $90 \%$ of the $\mathrm{CO}_{2} \mathrm{BOLs}$ regeneration duty, producing an estimated $40 \mathrm{MWe}$ more power than $\mathrm{CO}_{2} \mathrm{BOLs}$ alone, and $121 \mathrm{MWe}$ more power than Case 10.

The other parameters besides energy that contribute to economic projections for modeled cases include variable and fixed costs, as well as capital costs. Estimates for these values are shown in Tables 4 and 5.

Tables 4 and 5 highlight the variable costs, previously modeled cases, and the new sitespecific North Valmy cases. We point out that Variable and Total Capital costs for the Valmy system could not be gathered from site operators, so we used the values from the Case 9 study. This enables us to provide a comparison between Case 9 and North Valmy for the TEA, which the results are tabulated in Table 6 and illustrated in Figure 9. It should be noted that these numbers are to be used as a relative not absolute comparison of cost impacts on the aforementioned hybrid designs in this study. 
Table 5. Variable and fixed cost estimates for each model case

\begin{tabular}{|c|c|c|c|c|c|c|c|c|c|c|c|c|c|c|}
\hline \multirow[b]{2}{*}{ Varriable $\cos t(\$ k / y r)$} & \multicolumn{3}{|c|}{$\begin{array}{c}\text { No Carbon Capture } \\
\text { (Case } 9 \text { reference: Subritical PC) }\end{array}$} & \multicolumn{4}{|c|}{ Mo Carbon Capture } & \multicolumn{2}{|c|}{ Morth Valmy Cases } & \multirow{2}{*}{$\begin{array}{l}\text { Whith Carbon } \\
\text { Capture } \\
\text { ICase } 10 \\
\text { Case } 10 \text { with } \\
\text { geothermal } \\
\text { for BFW, but } \\
\text { for } 7 \% \text { of } \\
\text { reboiler first }\end{array}$} & \multicolumn{3}{|c|}{0} & \multirow{2}{*}{$\begin{array}{c}\text { COZBOS } \\
\text { Updated } \\
\text { Predictions- } \\
\\
\text { Assumptions } \\
\text { (list below) }\end{array}$} \\
\hline & $\begin{array}{l}\text { Case } 9 \text { Only } \\
\text { (rerreated) }\end{array}$ & $\begin{array}{c}\text { Case } 9 \text { with } \\
\text { geothermal } \\
\text { for BFW } \\
\text { heating }\end{array}$ & \begin{tabular}{|c|} 
Case 9 Only \\
with \\
geothermal \\
for Bew, but \\
through ORC [i \\
Buttane] first
\end{tabular} & $\begin{array}{c}\text { Morth Valmy } \\
\text { (recreated) }\end{array}$ & $\begin{array}{c}\text { Morth Valmy } \\
\text { baseline w/ } \\
\text { geothemal } \\
\text { for BAW 1300 } \\
\text { Epm }\end{array}$ & $\begin{array}{c}\text { Morth Valmy } \\
\text { baseline w/ } \\
\text { geothermal } \\
\text { for BFW 650 } \\
\text { Epm }\end{array}$ & $\begin{array}{l}\text { Morth Valmy } \\
\text { basefine w/ } \\
\text { geothermal } \\
\text { for BPW 1300 } \\
\text { Epm ZX Wells }\end{array}$ & $\begin{array}{l}\text { Morth Valmy } \\
\text { 92 F a } \\
\text { cooling with } \\
\text { Geothermal } \\
\text { wet/dry } \\
\text { cooling }\end{array}$ & $\begin{array}{l}\text { Case } 10 \text { Only } \\
\text { (rerreated) }\end{array}$ & & $\begin{array}{l}\text { Case } 10 \text { with } \\
\text { geothermal } \\
\text { for BrW, but } \\
\text { for } 100 \% \text { of } \\
\text { reboiler first }\end{array}$ & $\begin{array}{l}\text { Case } 10 \text { with } \\
\text { low viscosity } \\
\text { CO2BOSts } \\
\text { solwent vs. } \\
\text { MEA (mo } \\
\text { geothermal) }\end{array}$ & \begin{tabular}{|c|} 
Case $10 \mathrm{wI}$ \\
cO2BOLs, \\
BFW via \\
geothermal \\
but for 90\% of \\
reboiler first
\end{tabular} & \\
\hline \multicolumn{15}{|l|}{ Non-Capture System: } \\
\hline Maintenance Material Cost & $\$ 8,763$ & $\$ 8,763$ & $\$ 8,763$ & $\$ 8,763$ & $\$ 8,763$ & $\$ 8,763$ & $\$ 8,763$ & $\$ 8,763$ & $\$ 8,763$ & $\$ 15,644$ & $\$ 15,644$ & $\$ 15,644$ & $\$ 15,644$ & $\$ 15,644$ \\
\hline Water & $\$ 1,425$ & $\$ 1,425$ & $\$ 1,425$ & $\$ 1,425$ & $\$ 1,425$ & $\$ 1,425$ & $\$ 1,425$ & $\$ 1,425$ & $\$ 1,425$ & $\$ 2,712$ & $\$ 2,712$ & $\$ 2,712$ & $\$ 2,712$ & $\$ 2,712$ \\
\hline MU \& WT Chem & $\$ 1,103$ & $\$ 1,103$ & $\$ 1,103$ & $\$ 1,103$ & $\$ 1,103$ & $\$ 1,103$ & $\$ 1,103$ & $\$ 1,103$ & $\$ 1,103$ & $\$ 2,100$ & $\$ 2,100$ & $\$ 2,100$ & $\$ 2,100$ & $\$ 2,100$ \\
\hline Limestone & $\$ 3,496$ & $\$ 3,496$ & $\$ 3,496$ & $\$ 3,496$ & $\$ 3,496$ & $\$ 3,496$ & $\$ 3,496$ & $\$ 3,496$ & $\$ 3,496$ & $\$ 5,043$ & $\$ 5,043$ & $\$ 5,043$ & $\$ 5,043$ & $\$ 5,043$ \\
\hline Ammonia (28\% NH3) & $\$ 3,136$ & $\$ 3,136$ & $\$ 3,136$ & $\$ 3,136$ & $\$ 3,136$ & $\$ 3,136$ & $\$ 3,136$ & $\$ 3,136$ & $\$ 3,136$ & $\$ 4,446$ & $\$ 4,446$ & $\$ 4,446$ & $\$ 4,446$ & $\$ 4,446$ \\
\hline SCR Catalyst & $\$ 593$ & $\$ 593$ & $\$ 593$ & $\$ 593$ & $\$ 593$ & $\$ 593$ & $\$ 593$ & $\$ 593$ & $\$ 593$ & $\$ 832$ & $\$ 832$ & $\$ 832$ & $\$ 832$ & $\$ 832$ \\
\hline Ayash Dikposal & $\$ 2,050$ & $\$ 2,050$ & $\$ 2,050$ & $\$ 2,050$ & $\$ 2,050$ & $\$ 2,050$ & $\$ 2,050$ & $\$ 2,050$ & $\$ 2,050$ & $\$ 2,882$ & $\$ 2,882$ & $\frac{\$ 032}{\$ 2,882}$ & $\$ 2,882$ & $\frac{\$ 302}{\$ 2,882}$ \\
\hline Bottom Ash Disposal & $\$ 512$ & $\$ 512$ & $\$ 512$ & $\$ 512$ & $\$ 512$ & $\$ 512$ & $\$ 512$ & $\$ 512$ & $\$ 512$ & $\$ 720$ & $\$ 720$ & $\$ 720$ & $\$ 720$ & $\$ 720$ \\
\hline \multicolumn{15}{|l|}{ Capture System: } \\
\hline Solvent & \$0 & \$o & \$0 & \$0 & \$0 & \$0 & \$o & \$o & \$0 & $\$ 1,106$ & $\$ 1,106$ & $\$ 1,106$ & $\$ 1,106$ & $\$ 4,826$ \\
\hline $\mathrm{NaOH}$ & \$o & \$o & \$0 & \$0 & \$0 & \$o & so & so & \$o & $\$ 1,062$ & $\$ 1,062$ & $\$ 1,062$ & $\$ 1,062$ & $\$ 4,071$ \\
\hline H2SO4 & \$0 & so & \$0 & \$0 & so & \$o & 20 & so & 50 & $\$ 324$ & $\$ 324$ & $\$ 324$ & $\$ 324$ & $\$ 496$ \\
\hline Corrosion inhibitor & \$0 & \$o & \$0 & \$0 & \$o & so & \$o & \$o & \$0 & $\$ 7$ & $\$ 7$ & $\$ 7$ & $\$ 7$ & \$0 \\
\hline Activated Carbon & so & so & $\$ 0$ & so & so & \$0 & so & so & \$0 & $\$ 616$ & $\$ 616$ & $\$ 616$ & $\$ 616$ & $\$ 617$ \\
\hline Iotal $(\mathbf{s} \mathrm{k} / \mathrm{rr})$ & $\$ 21,078$ & $\$ 21,078$ & $\$ 21,078$ & $\$ 21,078$ & $\$ 21,078$ & $\$ 21,078$ & $\$ 21,078$ & $\$ 21,078$ & $\$ 21,078$ & $\$ 37,496$ & $\$ 37,496$ & $\$ 37,496$ & $\$ 37,496$ & $\$ 44,391$ \\
\hline Variable Operating Cost (c/kWe-hr) & 0.52 & 0.50 & 0.51 & 0.54 & 0.53 & 0.55 & 0.54 & 0.54 & 0.52 & 0.88 & 0.77 & 0.80 & 0.75 & 50675.02 \\
\hline \multicolumn{15}{|l|}{ Fixed Openting Costs (Sk/vr) } \\
\hline Operating Lator & $\$ 5,524$ & $\$ 5,524$ & $\$ 5,524$ & $\$ 5,524$ & $\$ 5,524$ & $\$ 5,524$ & $\$ 5,524$ & $\$ 5,524$ & $\$ 5,524$ & $\$ 6,445$ & $\$ 6,445$ & $\$ 6,445$ & $\$ 6,445$ & $\$ 6,445$ \\
\hline Maintenance Labor & $\$ 5,842$ & $\$ 5,842$ & $\$ 5,842$ & $\$ 5,842$ & $\$ 5,842$ & $\$ 5,842$ & $\$ 5,842$ & $\$ 5,842$ & $\$ 5,842$ & $\$ 10,430$ & $\$ 10,430$ & $\$ 10,430$ & $\$ 10,430$ & $\$ 10,430$ \\
\hline Adtministrative \& Support Labor & $\$ 2,842$ & $\$ 2,842$ & $\$ 2,842$ & $\$ 2,842$ & $\$ 2,842$ & $\$ 2,842$ & $\$ 2,842$ & $\$ 2,842$ & $\$ 2,842$ & $\$ 4,219$ & $\$ 4,219$ & $\$ 4,219$ & $\$ 4,219$ & $\$ 4,219$ \\
\hline Property Taxes and hssurance & $\$ 17,849$ & $\$ 17,849$ & $\$ 17,849$ & $\$ 17,849$ & $\$ 17,849$ & $\$ 17,849$ & $\$ 17,849$ & $\$ 17,849$ & $\$ 17,849$ & $\$ 32,367$ & $\$ 32,367$ & $\$ 32,367$ & $\$ 32,367$ & $\$ 32,367$ \\
\hline Total & $\$ 32,057$ & $\$ 32,057$ & $\$ 32,057$ & $\$ 32,057$ & $\$ 32,057$ & $\$ 32,057$ & $\$ 32,057$ & $\$ 32,057$ & $\$ 32,057$ & $\$ 53,460$ & $\$ 53,460$ & $\$ 53,460$ & $\$ 53,460$ & $\$ 53,460$ \\
\hline Fixed Operating Cost (c/kWe-hr) & 0.79 & 0.77 & 0.78 & 0.82 & 0.81 & 0.84 & 0.82 & 0.82 & 0.78 & 1.26 & 1.10 & 1.14 & 1.07 & 61027.64 \\
\hline
\end{tabular}


Table 6. Capital cost estimates for each model case

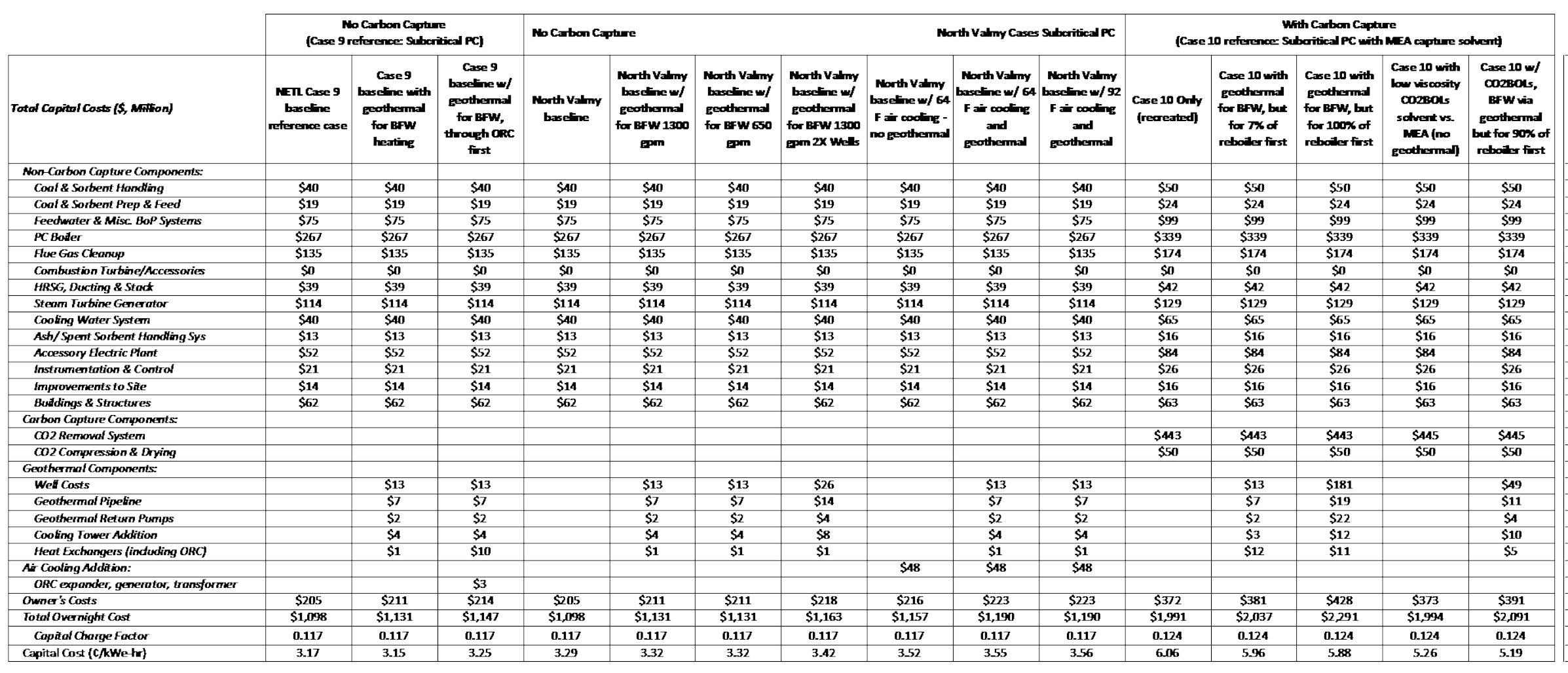


Table 7. Levelized cost of electricity estimates for each model case

\begin{tabular}{|c|c|c|c|c|c|c|c|c|c|c|c|c|c|c|c|c|}
\hline \multirow[b]{2}{*}{ mmary of Cossts $(c / k$ We hr) } & \multicolumn{3}{|c|}{$\begin{array}{l}\text { Mo Carbon Capture } \\
\text { (Gase } 9 \text { refirence: Subriticad PC) }\end{array}$} & \multicolumn{7}{|c|}{$\begin{array}{l}\text { Mo Garton Gapture } \\
\text { (Morth Valley reference: Subcribical PC) }\end{array}$} & \multicolumn{5}{|c|}{$\begin{array}{l}\text { Writ Carbon Cupture } \\
\text { (Gase } 10 \text { reference: Subcritical PC with MEA Capture solvent) }\end{array}$} & \multirow[b]{2}{*}{ Assumptions } \\
\hline & $\begin{array}{c}\text { Merl Case 9 } \\
\text { bassetine } \\
\text { reforence case }\end{array}$ & $\begin{array}{c}\text { Case } 9 \\
\text { basefine with } \\
\text { geothennal } \\
\text { for Brw } \\
\text { hesting }\end{array}$ & 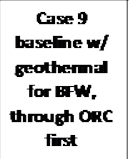 & $\begin{array}{l}\text { Morth Valumy } \\
\text { basetine }\end{array}$ & $\begin{array}{c}\text { Morth Valuy } \\
\text { basefine w/ } \\
\text { geothennal } \\
\text { for Brw } 1300 \\
\text { gpen }\end{array}$ & $\begin{array}{c}\text { Morth Valny } \\
\text { basefine w/ } \\
\text { geothernal } \\
\text { for BFW } 650 \\
\text { gpen }\end{array}$ & 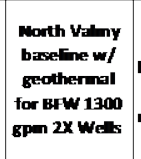 & 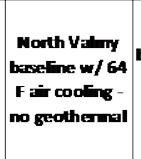 & 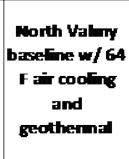 & 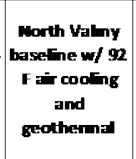 & $\begin{array}{l}\text { Crse } 10 \text { Only } \\
\text { (recrested) }\end{array}$ & $\begin{array}{l}\text { Crse } 10 \text { with } \\
\text { geothentinal } \\
\text { for BFW, but } \\
\text { for } 7 \% \text { of } \\
\text { reboiler first }\end{array}$ & $\begin{array}{l}\text { Case } 10 \text { with } \\
\text { geothental } \\
\text { for BFw, but } \\
\text { for } 100 \% \text { of } \\
\text { reboiler first }\end{array}$ & 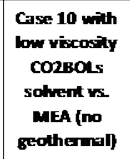 & 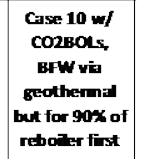 & \\
\hline Fuel Cost & 1.54 & 149 & 1.51 & 207 & 203 & 2.03 & 203 & 210 & 206 & 207 & 214 & 206 & 1.80 & 1.86 & 1.24 & 2 \\
\hline Capital Cost & 3.17 & 3.15 & 3.25 & 3.29 & 3.32 & 3.42 & 3.32 & 3.52 & 3.55 & 3.56 & 6.06 & 5.96 & 5.88 & 5.26 & 5.19 & 2 \\
\hline Variable Cost & 0.52 & 0.50 & 0.51 & 0.54 & 0.53 & 0.53 & 0.53 & 0.55 & 0.54 & 0.54 & 0.92 & 0.88 & $0 . \pi$ & 0.94 & 0.89 & 2 \\
\hline Fixed Operating Cost & 0.79 & $0 . \pi$ & 0.78 & 0.82 & 0.81 & 0.81 & 0.81 & 0.84 & 0.82 & 0.82 & 131 & 126 & 1.10 & 1.14 & 107 & 2 \\
\hline Transp, Seques \& Monitoring (ISM) & & & & & & & & & & & 0.59 & 0.57 & 0.50 & 0.51 & 0.48 & 8 \\
\hline Total & 6.02 & 5.91 & 6.06 & 673 & 6.69 & 6.79 & 6.69 & 7.01 & 6.97 & 699 & 11.01 & 10.72 & 1206 & 9.71 & 887 & 2 \\
\hline Cost increase morsus basefine & & $-1.9 x$ & $0.6 x$ & $\overline{-}$ & $0.5 x$ & $0.9 \mathbf{x}$ & $-0.5 x$ & 4.73x & $3.6 x$ & 4.0x & $\mathbf{8 3 9}$ & $\boldsymbol{7 B X}$ & $67 x$ & $6 \mathbf{6 1 X}$ & $4 \pi x$ & 2 \\
\hline
\end{tabular}

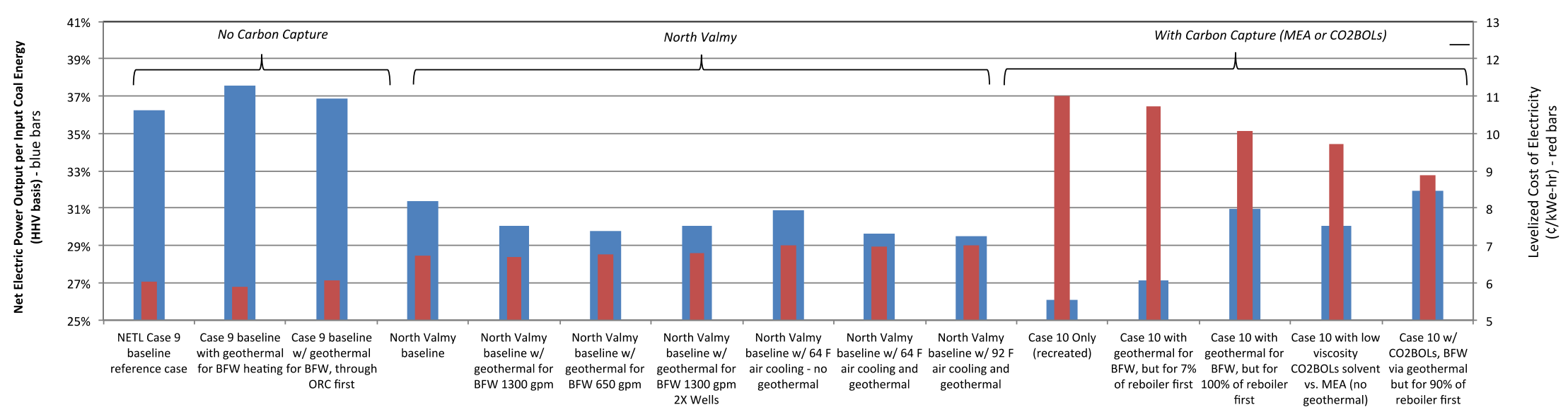

Figure 8. Comparison of net electric power and levelized cost of electricity estimates for each model case 
We calculate the site-specific North Valmy cases as we had for the Case 9 and 10 designs from the previous year's study. We provide the LCOE values for each of the modeled cases, based on the sub-elements of fuel, capital variable, fixed and transportation, sequestration, and monitoring costs from the preceding tables. A graphical representation of the LCOE values and net plant efficiency are plotted in Figure 9, along with the net power output per input coal energy for each of the modeled cases.

The key takeaways from the previous study are listed again for reference:

- Using $150^{\circ} \mathrm{C}$ geothermal water for boiler feed water preheating appears to offer a higher net electric power, at a comparable LCOE, compared to a stand-alone Case 9 subcritical power plant option. Also, as mentioned above, first passing the geothermal water through an ORC prior to using it for boiler feed water preheating is estimated to produce less overall net power than using it for boiler feed water preheating alone.

- The modeling cases with MEA carbon capture indicate the current challenges around the economics associated with carbon capture. Unfortunately, massive amounts of geothermal water are required to fully offset the MEA regeneration energy need, which are not feasible amounts of geothermal resource for a single site.

- A modest geothermal resource $(2,695,600 \mathrm{lb} / \mathrm{hr})$ is estimated to offset $7 \%$ of a MEA reboiler duty in Case 10, resulting in $\sim 1 \%$ of recovered net electric power lost to the overall CCS parasitic load, but at a similar (high) LCOE to CCS alone.

- The $\mathrm{CO}_{2} \mathrm{BOLs}$ cases indicate a more significant opportunity for $150^{\circ} \mathrm{C}$ geothermal water use than with the MEA solvent, with 0.75 cents per kWe-hr projected LCOE savings and $\sim 2$ points of net electric power increase versus $\mathrm{CO}_{2} \mathrm{BOLs}$ alone. This opportunity reflects the lower regeneration temperature and duty for $\mathrm{CO}_{2} \mathrm{BOLs}$ and similar advanced solvents.

- It is important to note that the model case result could significantly change with higher (or lower) geothermal water temperatures. Economic sensitivities to geothermal temperature may be worth exploring in subsequent efforts.

The key takeaways from the site-specific North Valmy analysis are as follows:

- North Valmy is less efficient than the NETL Case 9 plant, with net efficiency of $\sim 31 \%$ and a LCOE (assuming identical capital and variable costs as Case 9) of 6.06 cents per kWe-hr.

- If $125^{\circ} \mathrm{C}$ water is available at North Valmy at the rates assumed in this study, boiler feed water heating could enable $10.1 \mathrm{MW}$ gains in net power, though this is smaller than the 19 $\mathrm{MW}$ estimated if $150^{\circ} \mathrm{C}$ water is available under the plant.

- LCOE for $125^{\circ} \mathrm{C}$ boiler feed water integration is $1 \%$ increased efficiency for the plant with 0.04 cents per kWe-hr decrease.

- Half-flow of $125^{\circ} \mathrm{C}$ water produces 5.4 MW of power with the same capital expenditures of the full flow case, resulting in a 0.06 cents per kWe-hr increase. 
- Assuming half the flow of resource at $125^{\circ} \mathrm{C}$, doubling the number of wells to reach full flow of $125^{\circ} \mathrm{C}$ water results in the $10.1 \mathrm{MW}$ of power with a doubling of geothermal capital (53 MM USD total), resulting in a LCOE increase of 0.10 cents per kWe-hr.

- The addition of dry cooling to the plant could save an estimated 2.9 billions of gallons of ground water per year at the cost of 48 million USD at a modest power draw of $8 \mathrm{MW}$ with smaller land requirements (112 acres) than the evaporating ponds currently in use (150 acres).

- The power gains from integrating geothermal boiler feed water heating are enough to power the dry cooling, offering an increase in efficiency over the recreated North Valmy case by $<1 \%$, at a slight COE increase of 0.28 cents per kWe-hr.

- Wet and dry cooling also saves 2.9 billion gallons of water per year at comparable plant efficiencies with a modest 0.24 cents per kWe-hr increase.

Given the uncertainty in assumed flow rates for the Valmy Formation at the plant site, two cases were modeled to examine the impact of halving per-well flow rate on overall economics at North Valmy. The first case reflects a scenario in which only half the flow rate is available from the same number of wells; in the second, the same rate is maintained by doubling the well infrastructure, and associated capital expenses. In the reduced-production case, less power is produced, resulting in a $0.06 \mathrm{c} / \mathrm{kWh}$ increase in LCOE. In the higher-capital case, where twice as many wells are required to produce the same amount of water, LCOE increases $0.10 \mathrm{c} / \mathrm{kWh}$ due to both higher capital costs and higher operating costs. In either case, a 50 percent reduction in the flow rate per well has significant negative impacts on overall cost of electricity.

\subsection{Discussion}

Sitting atop a known (albeit poorly characterized) hydrothermal system, the North Valmy plant is unique among the U.S. coal-fired power fleet. However, taking North Valmy as a case study for quantitative evaluation of how and where geothermal fluids might be integrated into conventional, industrial system designs, and what costs and benefits might derive from this, suggests that low-temperature geothermal resources may offer a complementary and adjunct application of geothermal energy in the near-term. While these resources fall below the temperature range necessary to make ORC generation cost effective, they are far more widely distributed than the high temperature geothermal resources of interest for current and nearterm development as baseload power. But, as shown in this study, by leveraging the enormous capital investments already present in the fossil-fired generation fleet, geothermal energy can be used to provide a significant net increase in nameplate capacity at modest incremental costs. As modeled at the North Valmy plant, applying low-temperature geothermal fluids for boiler feedwater preheating results in an increase in overall plant capacity up to $10.1 \mathrm{MWe}$, for an overnight capital cost of $\$ 53$ M USD, with an LCOE decrease of only $\$ 0.04$ cents per kWe-hr.

In the U.S. and beyond, the potential geographical match between existing, conventional power or other industrial facilities and low-grade geothermal resources may offer opportunities 
to implement geothermal hybrid approaches to address process-specific heat needs, improve efficiency, and increase utilization of renewable, zero-emission geothermal resources. The marginal increases in the cost of power, under the conditions assumed in this study, are quite small, on the order of only a few percent in most cases. In the longer view, as greenhouse gas emissions become more heavily regulated in the United States and abroad, capacity increases to conventional fossil-fired power generation that can be effected via renewable hybridization, without a significant net increase to $\mathrm{CO}_{2}$ emissions, could be increasingly attractive.

While beyond the current scope, the results of this study suggest a need to understand the extensibility of this approach to natural gas- and biomass-fired power generation, as well as energy intensive industrial processes. Such an understanding could help clarify the degree to which a potential market exists for hybridized geothermal systems, and could help to focus work on those sectors with the greatest potential for large-scale commercial adoption. Based on this preliminary case study, however, it appears that coupling low-temperature geothermal resources to industrial processes like power production may hold significant promise to meet the Geothermal Technology Office cost performance targets of $\$ .06 / \mathrm{kWh}$ and contribute meaningfully toward GTO's $300 \mathrm{MW}$ installed capacity goal.

\subsection{References}

1. "Cost and Performance Baseline for Fossil Energy Plants, Volume 1: Bituminous Coal and Natural Gas to Electricity," Revision 2, 2010, DOE/NETL-2010/1397.

2. Roberts, RJ., 1964. "Stratigraphy and structure of the Antler Peak quadrangle, Flumboldt and Lander Counties, Nevada", U.S. Geological Survey Professional Paper 459A, 93p.

3. Young, CM, 1999. "Whole-Rock Oxygen Isotope Traverses Across Gold-Bearing and Barron Structures, Lone Tree Complex, Nevada". Unpublished Thesis, Department of Earth and Environmental Science, New Mexico Institute of Mining and Technology, Socorro, NM 87801.

4. Trexler, DT., Koenig, BA, Ghusn Jr., G Flynn, T., and Bell, EJ. 1982. "Low to moderate temperature geothermal resource assessment for Nevada: Area Specific Studies, Pumpernickel Valley, Carlin and Moana," Final Report, June 1, 1981 July 31, 1982, work performed under U.S. Department of Energy contract no. AC08-81NV10220, 177p.

5. Lane, M, R Schweickert, and T DeRocher. 2012. "Use of seismic imaging to identify geothermal reservoirs at the Hot Pot area, Nevada", PROCEEDINGS, Thirty-Seventh Workshop on Geothermal Reservoir Engineering Stanford University, Stanford, California, January 30 - February 1, 2012 SGP-TR-194.

6. US Geological Survey and Nevada Burearu of Mines and Geology. 2006. "Quaternary fault and fold database of the United States", accessed October 28, 2014, at:http://earthquake.usgs.gov/hazards/qfaults/

7. Waring, G.A.1965. "Thermal Springs of the United States and other countries of the world- A summary", US Geological Survey Prof. Paper 492. 
8. Muffler, LPJ. 1979. "Assessment of geothermal resources of the United States- 1978", US Geological Survey Circular 790.

9. DOE, 2013. Advanced seismic data analysis program (The Hot Pot project): Phase 1 Report, DOE Award DE-EE0002839, 41p.

10. Butler, SJ, SK Sanyal, A Robertson-Tait, JW Lovekin, D Benoit. 2001. A case history of numerical modeling of a fault-controlled geothermal system at Beowawe, Nevada. Proceedings of the $26^{\text {th }}$ Workshop of Geothermal Reservoir Engineering, Stanford Univ, Stanford, CA. SGP-TR-168.

11. Shevenell, L. 2012. The estimated costs as a function of depth of geothermal development wells drilled in Nevada. Transactions (36). Geothermal Research Council.

12. Klein CW, Lovekin JW, SK Sanyal, 2004. "New Geothermal Site Identification and Qualification." GeothermEx, Inc

13. Bradys, unpublished data described in detail in reference 11.

14. Augustine, C, JW Tester, and B Anderson, 2006. "A Comparison of Geothermal With Oil and Gas Well Drilling Costs." PROCEEDINGS, Thirty-First Workshop on Geothermal Reservoir http://www2.cemr.wvu.edu/ anderson/papers/SGP-TR-179.pdf

15. http://pubs.usgs.gov/circ/1405/pdf/circ1405.pdf.

\subsection{Supplemental Information}

The flow diagrams recreated by Pacific Northwest National Laboratory are shown below in Figures Supplementary (S) 1-3. Here, the Case 9 flow diagram is shown with feed water pre-heat (S1) and compared to an ORC (S2). The steam cycle for Case 10 is shown below in Figure S(3). Also, the geothermal well layout from ASPEN plus is shown in Figure $S(4)$. The net power calculations and results of the simulations are provided in Figures $S(5)$ and $S(6)$. 
Figure S(1). Aspen plus model of the DOE Case 9 subcritical steam cycle with feed water preheat

NETL CASE9 Rev2 Steam Cycle

Case9SteamSystemGeothermalAP84QBFW-PI PE5-CTW.apwz

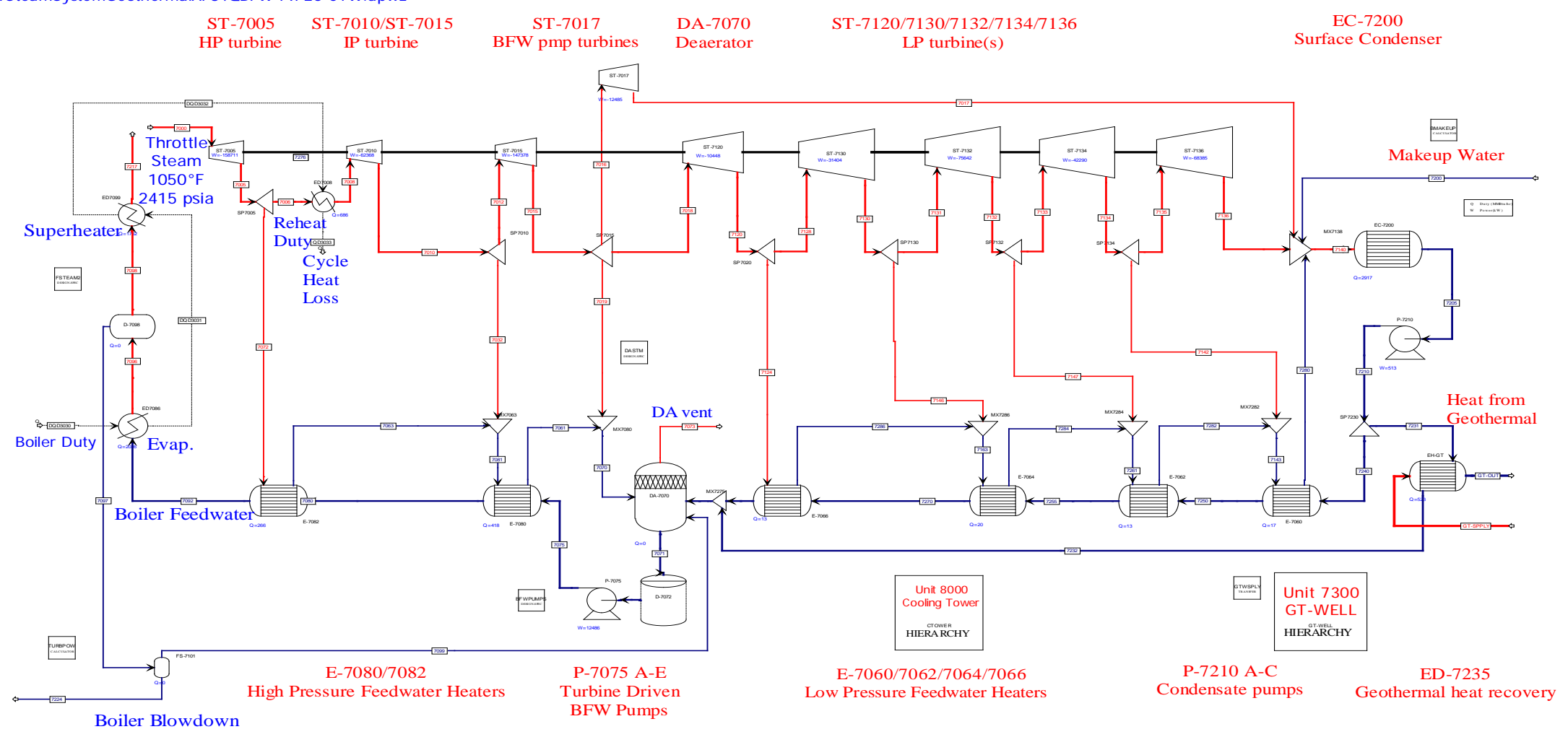




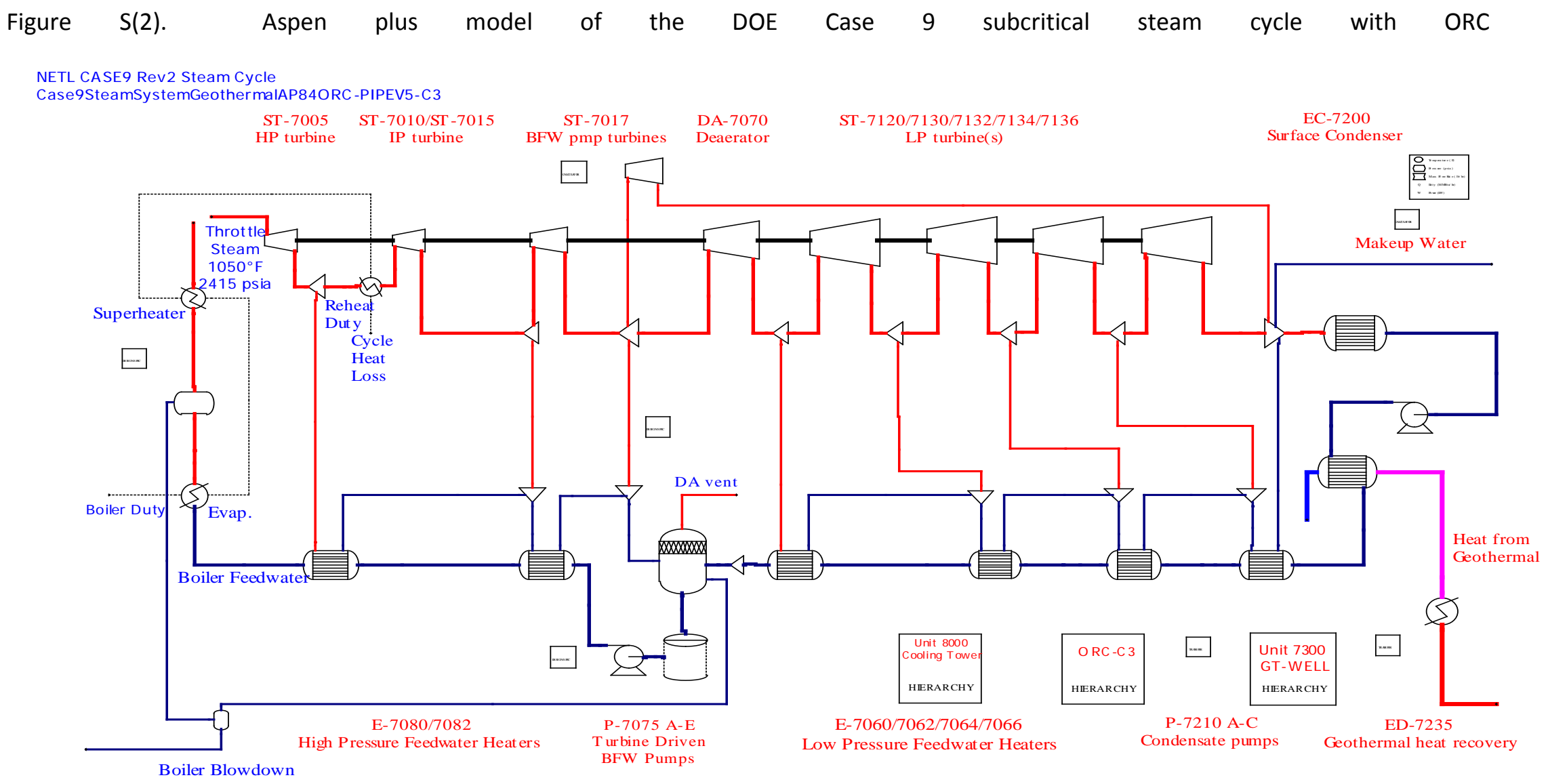




\section{Figure $\mathrm{S}(3)$. Aspen plus model of the DOE 10 subcritical steam cycle}

NETL CASE10 Rev2A Steam Cycle
CaseloSteamSystemWithGeothermalAP84V2

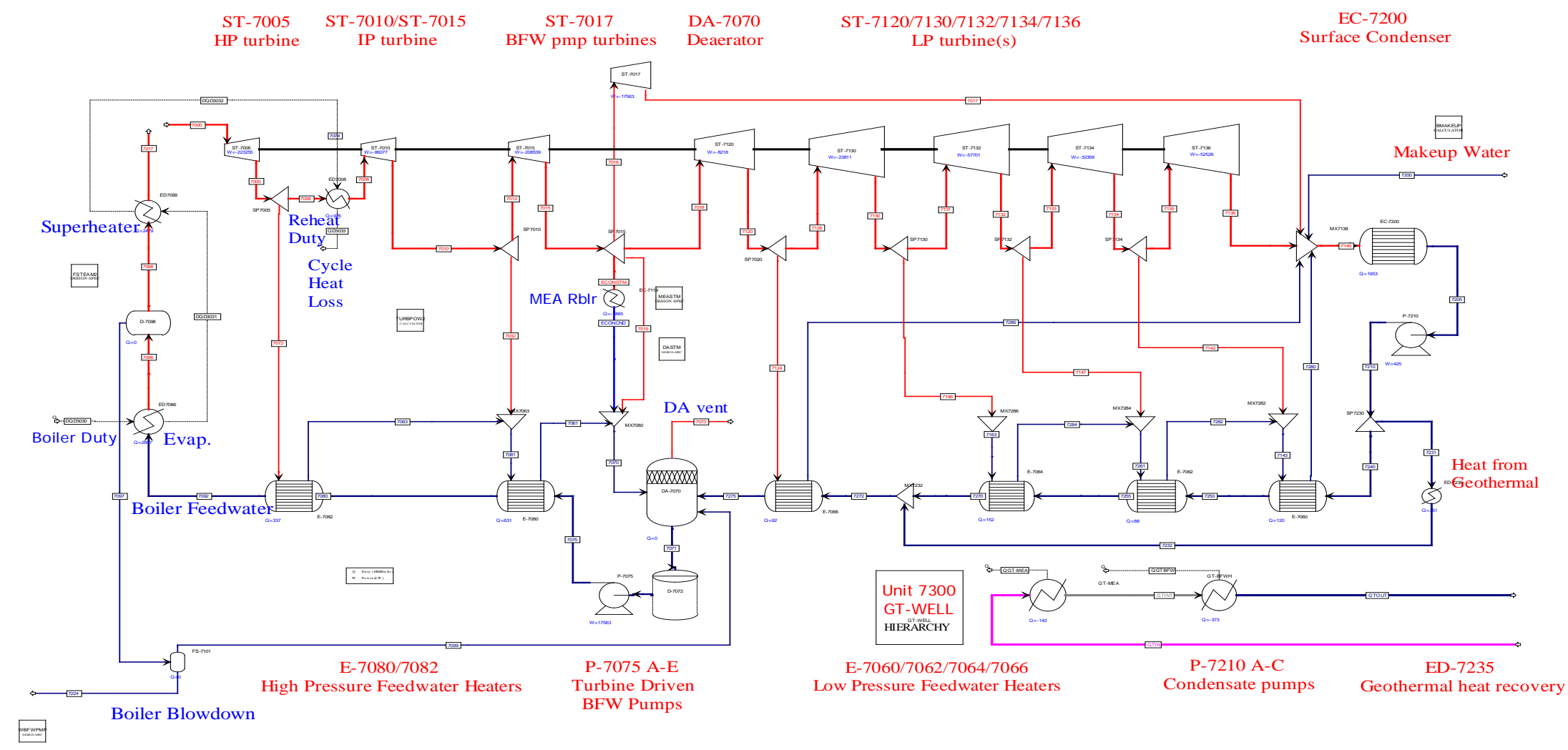


Figure S(4). ASPEN plus model geothermal well diagrams
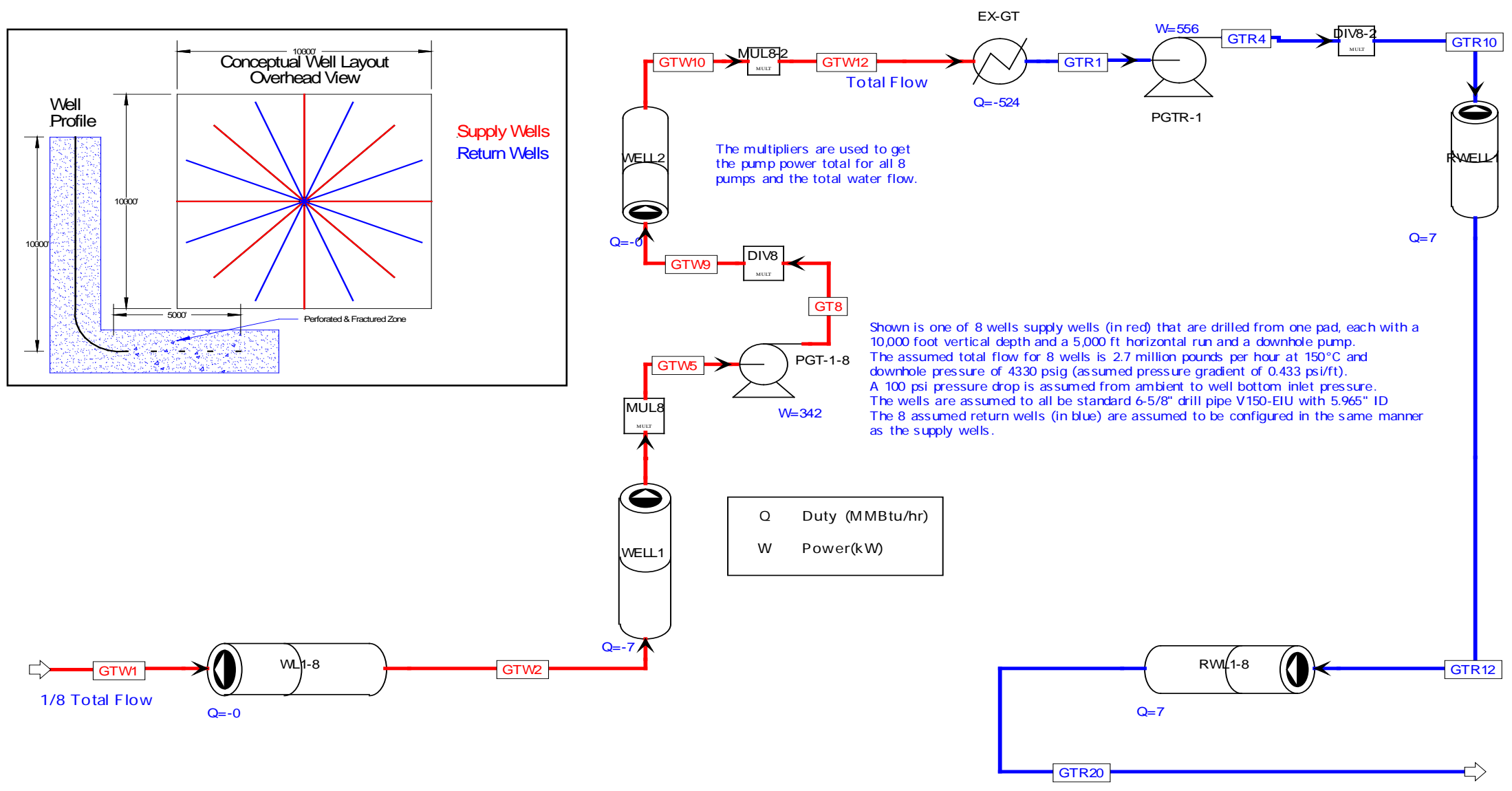
Figure S(5). Summarized projections for Integration of geothermal /coal-fired plants hybrid plants vs. standalone ORC

\begin{tabular}{|c|c|c|c|c|c|c|}
\hline \multicolumn{2}{|c|}{ Power Summaries - No Carbon Capture } & \multirow{3}{*}{$\begin{array}{l}\text { PNNL Case } 9 \\
\text { No Geothermal }\end{array}$} & \multirow{3}{*}{$\begin{array}{c}\text { PNNL Case } 9 \\
\text { Geothermal } \\
\text { BFW Heating }\end{array}$} & \multirow{3}{*}{$\begin{array}{l}\text { PNNL Case } 9 \\
\text { Geothermal } \\
\text { ORC - Ammor }\end{array}$} & \multirow{3}{*}{$\begin{array}{l}\text { PNNL Case } 9 \\
\text { Geothermal } \\
\text { ORC - Propan }\end{array}$} & \multirow{3}{*}{$\begin{array}{c}\text { PNNL Case } 12 \\
\text { Geothermal } \\
\text { ORC - i-Butane }\end{array}$} \\
\hline Power in kWe & & & & & & \\
\hline Duty in MMBtu/hr & NETL CASE 9 & & & & & \\
\hline AREA7100.ST-7005 & & 158,711 & 158,668 & 158,453 & 158,453 & 158,453 \\
\hline AREA7100.ST-7010 & & 62,572 & 62,555 & 62,233 & 62,233 & 62,233 \\
\hline AREA7100.ST-7015 & & 147,858 & 147,818 & 147,058 & 147,058 & 147,058 \\
\hline AREA7100.ST-7120 & & 10,515 & 10,476 & 10,273 & 10,291 & 10,352 \\
\hline AREA7100.ST-7130 & & 30,464 & 31,488 & 29,762 & 29,815 & 29,991 \\
\hline AREA7100.ST-7132 & & 69,391 & 75,845 & 67,792 & 67,912 & 68,313 \\
\hline AREA7100.ST-7134 & & 37,393 & 42,403 & 36,531 & 36,596 & 36,812 \\
\hline AREA7100.ST-7136 & & 57,427 & 68,568 & 59,073 & 59,178 & 59,527 \\
\hline AREA7100.ORC turbine & $\mathrm{N} / \mathrm{A}$ & $\mathrm{N} / \mathrm{A}$ & $\mathrm{N} / \mathrm{A}$ & 12,101 & 15,810 & 15,767 \\
\hline Gross Steam Turbine Power * kW & 582,600 & 574,331 & 597,822 & 583,274 & 587,346 & 588,505 \\
\hline Coal \& Miscellaneous Auxiliaries * & 21,360 & 21,360 & 21,360 & 21,360 & 21,360 & 21,360 \\
\hline CTW circulating pumps & 5,250 & 4,963 & 5,844 & 5,938 & 5,922 & 5,896 \\
\hline Cooling Tower fans *** & 2,720 & 2,770 & 3,262 & 3,314 & 3,305 & 3,291 \\
\hline Geothermal Well injection pumps & N/A & N/A & 3,039 & 3,039 & 3,039 & 3,039 \\
\hline Transformer loss *** & 1,830 & 1,804 & 1,878 & 1,832 & 1,845 & 1,848 \\
\hline Condensate pumps & 890 & 516 & 514 & 508 & 509 & 512 \\
\hline Ground Water pumps **** & 530 & 540 & 636 & 646 & 644 & 641 \\
\hline Total Auxiliaries kWe & 32,580 & 31,953 & 36,532 & 36,637 & 36,623 & 36,587 \\
\hline Net Power Production kWe & 550,020 & 542,379 & 561,289 & 546,637 & 550,723 & 551,918 \\
\hline Cooling Water Duty MMBtu/hr & 2,432 & 2,477 & 2,916 & 2,963 & 2,955 & 2,942 \\
\hline
\end{tabular}

* NETL Case 9 is net of BFW pumps

** Coal Handling, Ash Handling, Pulverization, Primary, Forced Draft and induced draft fans through FGD From Case9 (not sim

$\star * *$ Cooling tower fan power is ratioed from cooling water duty

**** Ground water pump power is ratioed from cooling water duty

Note: Aspen simulations in general produce less power and require substantially more

compression power than NETL report numbers

Note: BFW pumps are turbine driven and neither turbine drive power nor BFW pump

power appear in the net power calculation. 
Figure S(6). Summarized projections for Case 10 integration strategies of geothermal /coal-fired plants hybrid plants

\begin{tabular}{|c|c|c|c|c|c|}
\hline \multirow{2}{*}{$\begin{array}{l}\text { Power Summaries With Carbon Capture } \\
\text { Power in kWe } \\
\text { Duty in MMBtu/hr }\end{array}$} & \multirow{2}{*}{\multicolumn{2}{|c|}{\begin{tabular}{|l|l|} 
NETL CASE 10 & PNL Case 10 \\
No Geothermal
\end{tabular}}} & \multirow{2}{*}{\begin{tabular}{|l|} 
PNNL Case 10 \\
Partial Reboiler \\
Duty \& BFW Htg
\end{tabular}} & \multirow{2}{*}{\begin{tabular}{|l|} 
PNNL Case 10 \\
Max Reboiler \\
Duty \& BFW Htd
\end{tabular}} & \multirow{2}{*}{$\begin{array}{l}\text { PNNL Case } 10 \\
10 \mathrm{MMlb} / \mathrm{hr} \mathrm{GT} \\
70^{\circ} \mathrm{C} \text { Reboiler }\end{array}$} \\
\hline & & & & & \\
\hline AREA7100.ST-7005 & & 223,255 & 224,408 & 224,408 & 225,322 \\
\hline AREA7100.ST-7010 & & 86,077 & 86,522 & 86,522 & 86,874 \\
\hline AREA7100.ST-7015 & & 208,539 & 210,083 & 210,083 & 209,766 \\
\hline AREA710 & & 7,781 & 8,292 & 14,716 & 14,356 \\
\hline AREA7100.ST-7130 & & 22,542 & 23,775 & 42,193 & 41,378 \\
\hline & & 51,077 & & 102,248 & \\
\hline ARE & & 27,499 & 32,311 & 57,342 & 51,285 \\
\hline AREA7100.ST-7136 & & 42,181 & 52,447 & 93,077 & 83,246 \\
\hline Gross Steam Turbine Power kWe * & 672,700 & 668,950 & 695,453 & 830,588 & 807,486 \\
\hline Coal \& Miscellaneous Auxiliaries ** & & 30,470 & 30,470 & 30,470 & 30,470 \\
\hline MEA & & 231 & 268 & 584 & 19,584 \\
\hline & & & & 790 & 790 \\
\hline pumps &, 190 & 10,199 & 10,984 & 14,221 & 13,486 \\
\hline Coo & 5,820 & 7,791 & 8,383 & 10,854 & 10,293 \\
\hline ection pumps ${ }^{\star}$ & & & 3,039 & 50,879 & 7,954 \\
\hline Transfor & 2,350 & 2,337 & 2,429 & 2,901 & 2,821 \\
\hline & 700 & 405 & 432 & 723 & 707 \\
\hline Gro & 1,0 & 930 & 1,001 & 1,296 & 1,229 \\
\hline Total Auxiliaries kWe & 122,740 & 120,152 & 124,796 & 179,718 & 135,333 \\
\hline & & & & & \\
\hline Net Power Production & 549,960 & 548,799 & 570,657 & 650,870 & 672,153 \\
\hline $\begin{array}{l}\text { Cooling Water Duty } \\
\text { Total Reboiler Duty } \star \star \star \star \\
\text { Geothermal Reboiler Duty } \\
\text { Total Geothermal Duty } \\
\text { Geothermal Water Flow Ib/hr } \\
\text { Geothermal Water flow Bbl per day }\end{array}$ & 2008 & $\begin{array}{c}5,025 \\
2,008 \\
- \\
-\end{array}$ & $\begin{array}{r}2,008 \\
143 \\
517 \\
2,695,600 \\
184,693 \\
\end{array}$ & $\begin{array}{r}7,047 \\
2,008 \\
1,967 \\
2,577 \\
37,000,000 \\
2,535,115 \\
\end{array}$ & $\begin{array}{r}6,683 \\
1,500 \\
1,357 \\
1,605 \\
10,000,000 \\
685,166 \\
\end{array}$ \\
\hline 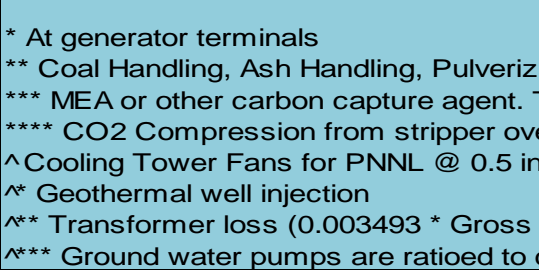 & $\begin{array}{l}\text { erhead pressure } \\
\text { nches water (NE } \\
\text { Steam Turbine }\end{array}$ & $\begin{array}{l}\text { has a hypotheti } \\
\text { e to } 2215 \text { psia fr } \\
\text { Power) }\end{array}$ & $\begin{array}{l}m \text { Case10 (A } \\
\text { wer) }\end{array}$ & simulation & $\begin{array}{l}\text { A and } 70^{\circ} \\
\text { 's higher }\end{array}$ \\
\hline
\end{tabular}


Figure S(7). LiBr cooling simulations

$\mathrm{LiBr}$ Absorption Refrigeration Driven by $125^{\circ} \mathrm{C}$ geothermal water $(2.65 \mathrm{MMlb} / \mathrm{hr})$ at maximum geothermal temperature swing

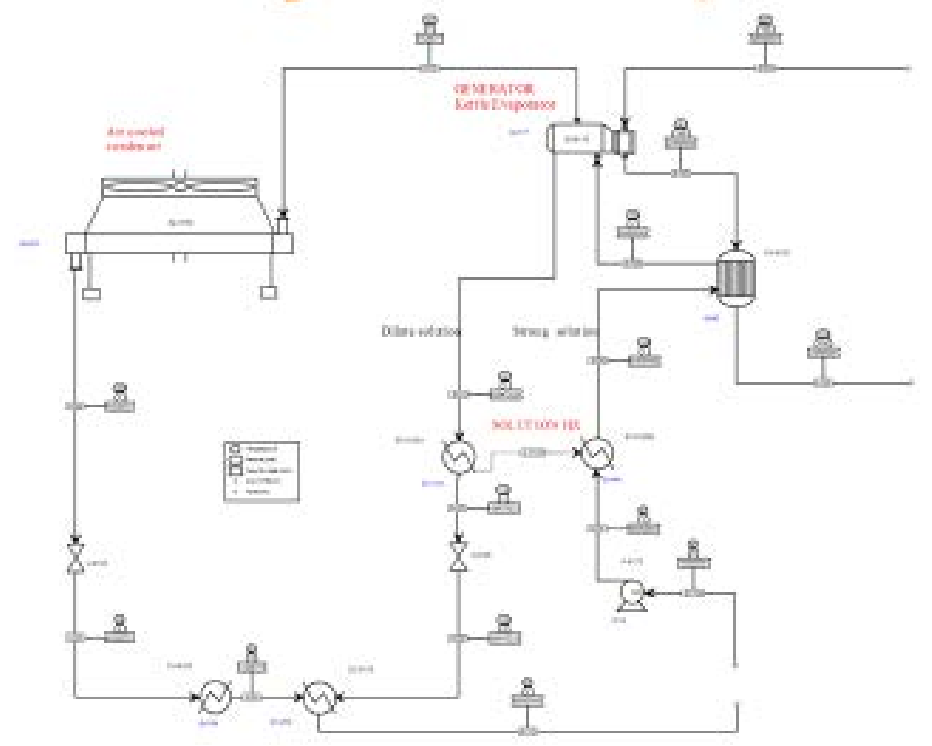

Maximum

Refrigeration

Duty Available

Is 155 MMBtuH

(id) $41^{\circ} \mathrm{F}$

Pacific Northwest

Prondily Operoded by Battelle Sime 1963

29

Figure $\mathrm{S}(8) \cdot \mathrm{NH}_{3}$ mechanical refrigeration

Ammonia Mechanical Refrigeration - Refrig. Power set equal to geothermal power increase

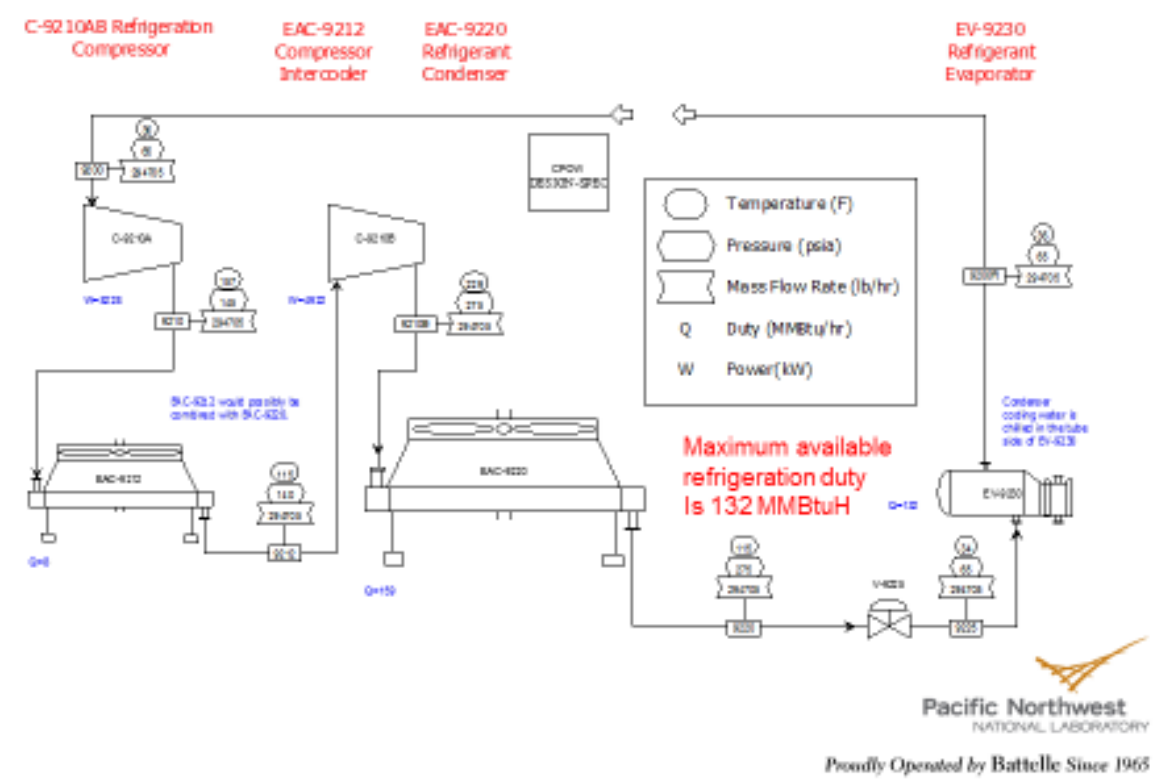

